\title{
Influence of combusting methane-hydrogen mixtures on compression-ignition engine exhaust emissions and in-cylinder gas composition
}

\author{
Midhat Talibi*, Ramanarayanan Balachandran, Nicos Ladommatos \\ Department of Mechanical Engineering, University College London, Torrington Place, London WC1E \\ 7JE, United Kingdom
}

\begin{abstract}
The paper presents an experimental investigation of combusting methane-hydrogen mixtures, pilotignited by diesel fuel, on a naturally aspirated, direct injection compression ignition engine. The tests were performed with two diesel fuel flow rates for pilot-ignition, and the engine was supplied with different quantities of methane-hydrogen mixtures (in various proportions) to vary the engine load between 0 and 7 bar IMEP. In addition, engine in-cylinder gas samples were collected with two geometric sampling arrangements and at various instants during the engine cycle, to measure species concentrations within the engine cylinder.

The results showed lower exhaust $\mathrm{CO}_{2}$ and particulate emissions at all engine loads when combusting methane-hydrogen mixtures as compared to diesel fuel only. $\mathrm{CO}$ and unburned THC emissions were higher for methane-hydrogen mixtures at all engine loads when compared with diesel fuel only. $\mathrm{NO}_{\mathrm{x}}$ emissions increased with increasing proportion of hydrogen in the aspirated mixture at all engine loads. In-cylinder $\mathrm{NO}_{x}$ levels were observed to be higher in the region between the fuel sprays as compared to within the spray core, attributable to higher temperatures reached in between the sprays post ignition.
\end{abstract}

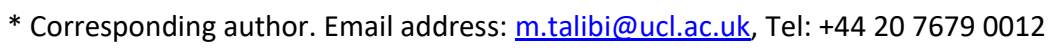




\section{Introduction}

Methane $\left(\mathrm{CH}_{4}\right)$ and hydrogen $\left(\mathrm{H}_{2}\right)$ are complimentary fuels in many aspects, as is evident from their physical and chemical properties $[1,2] . \mathrm{CH}_{4}$ is a relatively stable molecule and has an ignition energy requirement which is approximately 15 times greater than that of $\mathrm{H}_{2} . \mathrm{CH}_{4}$ can be difficult to combust completely in an engine or catalyse using exhaust after treatment systems. Operating engines on lean mixtures of $\mathrm{CH}_{4}$ and air has the associated drawback of low flame propagation velocities resulting in incomplete combustion, increased cycle-to-cycle variation and occasional flame failure [3]. The burning velocity of $\mathrm{CH}_{4}$ can be improved to some extent by optimizing the spark timing or increasing engine in-cylinder turbulence, which comes at a cost of increased peak cylinder gas temperatures and thus higher $\mathrm{NO}_{x}$ emissions [4]. One approach to accelerating $\mathrm{CH}_{4}$ combustion, without adversely affecting emission levels, is to add a small amount of $\mathrm{H}_{2}$ to $\mathrm{CH}_{4} . \mathrm{H}_{2}$ has a flame speed about six times higher than that of $\mathrm{CH}_{4}$ at atmospheric conditions $\left(42 \mathrm{~cm} / \mathrm{s}\right.$ for $\mathrm{CH}_{4}$ and 230 $\mathrm{cm} / \mathrm{s}$ for $\mathrm{H}_{2}$ ), and approximately eight times higher at typical engine pressure and temperature operating conditions [3]. Nagalingam et al. [5] conducted SI engine tests using natural gas supplemented by $\mathrm{H}_{2}$ and concluded that while the engine power output was reduced due to the lower volumetric heating value of $\mathrm{H}_{2}$ as compared to $\mathrm{CH}_{4}\left(2.8 \mathrm{MJ} / \mathrm{dm}^{3}\right.$ for $\mathrm{H}_{2}$ and $11.6 \mathrm{MJ} / \mathrm{dm}^{3}$ for $\mathrm{CH}_{4}$, at 350 bar, $25^{\circ} \mathrm{C}$ ), the considerably higher flame speed of $\mathrm{H}_{2}$ meant that less spark advance was required to produce maximum brake torque (MBT). Hence the very high flame speed of $\mathrm{H}_{2}$ allows shorter combustion duration leading to higher peak cylinder pressures and heat release rates and smaller time interval between fuel ignition and peak heat release, as compared to $\mathrm{CH}_{4}$. On the other hand, the presence of $\mathrm{CH}_{4}$ in $\mathrm{H}_{2}-\mathrm{CH}_{4}$ mixtures reduces the risk of combustion anomalies such as backfire and knock, usually associated with $\mathrm{H}_{2}$ combustion $[6,7]$.

There is considerable literature available, spanning a couple of decades, relating to the use of $\mathrm{CH}_{4}-\mathrm{H}_{2}$ mixtures in $\mathrm{SI}$ engines [3-5,8-22]; more recently, studies have been conducted using $\mathrm{CH}_{4}-\mathrm{H}_{2}$ mixtures in $\mathrm{Cl}$ engines, with the diesel fuel acting as an ignition source (pilot ignition). McTaggartCowan et al. [23] used a Cummins ISX series heavy-duty, single-cylinder diesel engine, with direct injection capabilities for both diesel and gaseous fuels, to investigate the combustion and emission characteristics of $\mathrm{CH}_{4}-\mathrm{H}_{2}$ mixtures pilot ignited with diesel fuel. From that study it was determined that $\mathrm{H}_{2}$ addition enhances the ignitability of the in-cylinder fuel mixture, resulting in shorter ignition delays. At low loads, the addition of $\mathrm{H}_{2}$ not only improved the rate of burning during the partially premixed stage, but also reduced cycle-to-cycle variability. In comparison, at high loads, a reduction in peak heat release rates was observed which was attributed to $\mathrm{H}_{2}$ having a lower energy density. The observed decrease in $\mathrm{CO}$, unburned total hydrocarbons (THC) and particulate mass (PM) 
emissions due to $\mathrm{H}_{2}$ addition was greater than which would result merely from the lower carbon content of the fuel. This was attributed to improved combustion stability and, hence, enhanced fuel oxidation rates. $\mathrm{NO}_{\mathrm{x}}$ emissions were observed to increase at all engine load conditions tested, which was attributed not only to hydrogen's higher flame temperatures, but also to the effect of $\mathrm{H}_{2}$ on the NO formation chemistry. Comparable observations were reported by Gatts et al. [24] who carried out similar tests; additionally, Gatts et al. [24] reported that the low combustion efficiency of natural gas was primarily due to $\mathrm{CH}_{4}$ remaining unburned in the combustion chamber, which showed an improvement upon the addition of $\mathrm{H}_{2}$.

Imran et al. [25] carried out a study on a single cylinder, direct injection $\mathrm{Cl}$ engine investigating the effects of varying the quantity of pilot diesel fuel; the engine was run, separately, on natural gas (NG) and $\mathrm{H}_{2}$ with the diesel fuel serving as the ignition source. A reduction in ignition delay was observed as the quantity of diesel fuel was increased with both NG and $\mathrm{H}_{2}$. At higher engine speeds and NG-diesel fuel engine operation, the specific $\mathrm{NO}_{x}$ emissions were found to be proportional to the quantity of diesel fuel injected [25]. However, at lower engine speeds a diesel fuel quantity threshold was observed where maximum $\mathrm{NO}_{\mathrm{x}}$ emissions were measured, with lower $\mathrm{NO}_{\mathrm{x}}$ levels observed at any other diesel fuel quantity. In the case of $\mathrm{H}_{2}$-diesel fuel mixtures, $\mathrm{NO}_{x}$ emissions were observed to decrease with increasing diesel fuel quantity at lower engine speeds, whereas, at high speeds $\mathrm{NO}_{x}$ levels were observed to increase with increasing quantity of the pilot diesel fuel [25].

Zhou et al. [26] investigated the effects of co-combusting $\mathrm{H}_{2}, \mathrm{CH}_{4}$ and $\mathrm{CH}_{4}-\mathrm{H}_{2}$ mixtures with diesel fuel, at constant engine loads, in a four cylinder $\mathrm{Cl}$ engine, on engine performance and pollutant emissions. The addition of $\mathrm{CH}_{4}$ to $\mathrm{H}_{2}$ was observed to make $\mathrm{H}_{2}$ combustion smoother, and the authors suggested that this could improve engine operational safety and mechanical durability [26]. Contrary to some reported studies in literature [27-29], a decrease in efficiency was observed when using $\mathrm{H}_{2}$-diesel fuel as compared to diesel fuel only operation; the authors [26] speculated that this could be an effect of the extremely small quenching distance of $\mathrm{H}_{2}(0.64 \mathrm{~mm}$ at $101.325 \mathrm{kPa}$ and 293 $\mathrm{K}$ ) leading to a higher thermal losses from the $\mathrm{H}_{2}$ flame as compared to the diesel only flame. $\mathrm{CO}$ and unburned $\mathrm{HC}$ emissions were observed to be higher for $\mathrm{CH}_{4}$-diesel fuel mixtures as compared to diesel fuel only operation. This was attributed to the partial oxidation of $\mathrm{CH}_{4}$ and some of the aspirated $\mathrm{CH}_{4}$ not combusting in the engine and persisting to the exhaust [26]. As expected, the replacement of either diesel fuel or $\mathrm{CH}_{4}$ by $\mathrm{H}_{2}$, led to a reduction in the emissions of $\mathrm{CO}$ and unburned $\mathrm{HC}$, due to displacement of carbon-containing fuel. A considerable rise in $\mathrm{NO}_{\mathrm{x}}$ emissions was observed when using $\mathrm{CH}_{4}$-diesel fuel or $\mathrm{H}_{2}$-diesel fuel mixtures, as compared to diesel fuel only operation. $\mathrm{NO}_{x}$ emissions were also observed to increase as $\mathrm{CH}_{4}$ was replaced by $\mathrm{H}_{2}$, due to the 
higher combustion temperatures of $\mathrm{H}_{2}$. It was suggested that a $\mathrm{H}_{2}$ rich mixture $\left(30 \mathrm{CH}_{4}-70 \mathrm{H}_{2}\right.$ by volume) improves engine performance and lowers $\mathrm{CO}$ and unburned $\mathrm{HC}$ emissions, whereas, a $\mathrm{CH}_{4}$ rich mixture $\left(70 \mathrm{CH}_{4}-30 \mathrm{H}_{2}\right.$ by volume) is effective in limiting $\mathrm{NO}_{x}$ formation rates and increasing combustion stability (avoiding phenomena such as uncontrolled pre-ignition of $\mathrm{H}_{2}$ ) [26]. Particulate emissions reduced when $\mathrm{H}_{2}$ was added to $\mathrm{CH}_{4}$-diesel fuel combustion; this observation agrees with the results of Wang et al. [30], which suggest that $\mathrm{H}_{2}$ moves the $\mathrm{CH}_{4}$ oxidation path towards a lower carbon reaction path, and hence reduces soot formation rates.

The above review of literature highlights the various characteristics of burning $\mathrm{CH}_{4}$ and $\mathrm{H}_{2}$ in $\mathrm{Cl}$ engines, and suggests that the use of $\mathrm{CH}_{4}-\mathrm{H}_{2}$ mixtures has the potential of favourably utilising the combustion properties of the individual gases. For example, the $\mathrm{CH}_{4}$ flame front could be accelerated by adding $\mathrm{H}_{2}$, while the increase in $\mathrm{NO}_{x}$ emissions as a consequence of $\mathrm{H}_{2}$ combustion could be countered by using $\mathrm{CH}_{4}$. This indicates that the proportion of the individual gases in the $\mathrm{CH}_{4}-\mathrm{H}_{2}$ mixture appreciably influences the combustion characteristics, and ultimately the exhaust emissions, and therefore it is quite important to find the correct balance of $\mathrm{CH}_{4}$ and $\mathrm{H}_{2}$ for optimum performance. This paper presents a comprehensive investigation utilizing various mixture ratios of $\mathrm{CH}_{4}$ and $\mathrm{H}_{2}$, from $\mathrm{CH}_{4}$-rich $\left(80 \mathrm{CH}_{4}: 2 \mathrm{H}_{2}\right)$ to $\mathrm{H}_{2}$-rich $\left(20 \mathrm{CH}_{4}: 80 \mathrm{H}_{2}\right)$ mixtures. Each of the $\mathrm{CH}_{4}-\mathrm{H}_{2}$ mixture was ignited using two different pilot diesel fuel flow rates, and the engine load was varied by varying the amount of $\mathrm{CH}_{4}-\mathrm{H}_{2}$ mixture being aspirated into the cylinder. The second part of the paper reports some in-cylinder sampling results, whereby a novel sampling system was used to analyse the in-cylinder gas composition at different instances of the combustion cycle, when combusting $\mathrm{CH}_{4}-\mathrm{H}_{2}$ mixtures. Apart from providing validation for the exhaust emission data, the in-cylinder tests were used to further our understanding of the in-cylinder combustion behaviour of $\mathrm{CH}_{4}-\mathrm{H}_{2}$ mixtures.

\section{Experimental Setup}

\subsection{Engine Facility}

The study reported in this paper was carried out on a single cylinder compression-ignition engine described in a previous publication [31]. The 2.0 litre 4-cylinder Ford Duratorq cylinder head, piston, liner and connecting rod were mounted on a Ricardo Hydra crankcase; geometry specifications for the engine are listed in Table 1. The engine crankshaft was connected directly to a David McClure dynamometer (DC200), which can motor the engine up to $5000 \mathrm{rpm}$, and hold it at constant speed when the engine is firing by absorbing and adjusting the torque resistance offered to the engine. The dynamometer was driven by the thyristor power unit and controlled by a Cussons test-bed control rack. The in-cylinder gas pressure was measured, to a resolution of 0.2 CAD, using a Kistler 6056A piezoelectric pressure transducer and a Kistler 5018 charge amplifier; the transducer was mounted 
on the engine via the glow plug adaptor. The engine pressure and temperature data was logged to PCs utilizing National Instruments (NI) data acquisition systems; information such as net apparent heat release rates and the indicated mean effective pressures were then derived from the acquired data.

A positive displacement volumetric air flow meter (Romet G65) measured the flow of air supplied to the naturally aspirated engine. $\mathrm{CH}_{4}$ and $\mathrm{H}_{2}$ gas were supplied from compressed gas bottles at a pressure of 2 bar, metered using Bronkhorst thermal mass flow controllers, and fed into the engine intake manifold $350 \mathrm{~mm}$ upstream of the inlet valves. The diesel fuel was gravity fed from the fuel reservoir to the high pressure pump, and was then pumped via the common rail to the fuel injector. An automotive Delphi DFI 1.3 (6 hole, $154 \mu \mathrm{m}$ hole diameter) servo-hydraulic solenoid valve fuel injector was used for the direct injection of diesel fuel; the pressure, timing and duration of diesel fuel injection was controlled using the EmTronix EC-GEN 500 engine control system.

A Horiba MEXA-9100HEGR exhaust gas analyser rack was utilized for the analysis of gaseous exhaust emissions; this incorporated a chemiluminescence analyser for $\mathrm{NO}_{\mathrm{x}}$ measurements, a magnetopneumatic analyser for measuring $\mathrm{O}_{2}$ concentration, a flame ionization detector for THC emissions and a non-dispersive infrared absorption analyser for $\mathrm{CO}$ and $\mathrm{CO}_{2}$ emissions. The Cambustion DMS500 differential mobility spectrometer was used to measure the exhaust particulate mass, number and size distribution. The exhaust gas was taken $30 \mathrm{~mm}$ downstream of the exhaust valves and transferred to the analysers via heated lines which were maintained at $190^{\circ} \mathrm{C}$ and $80^{\circ} \mathrm{C}$ for the Horiba MEXA and DMS500 respectively. Figure 1 shows a schematic of the test facility, including $\mathrm{CH}_{4}$ and $\mathrm{H}_{2}$ delivery. 


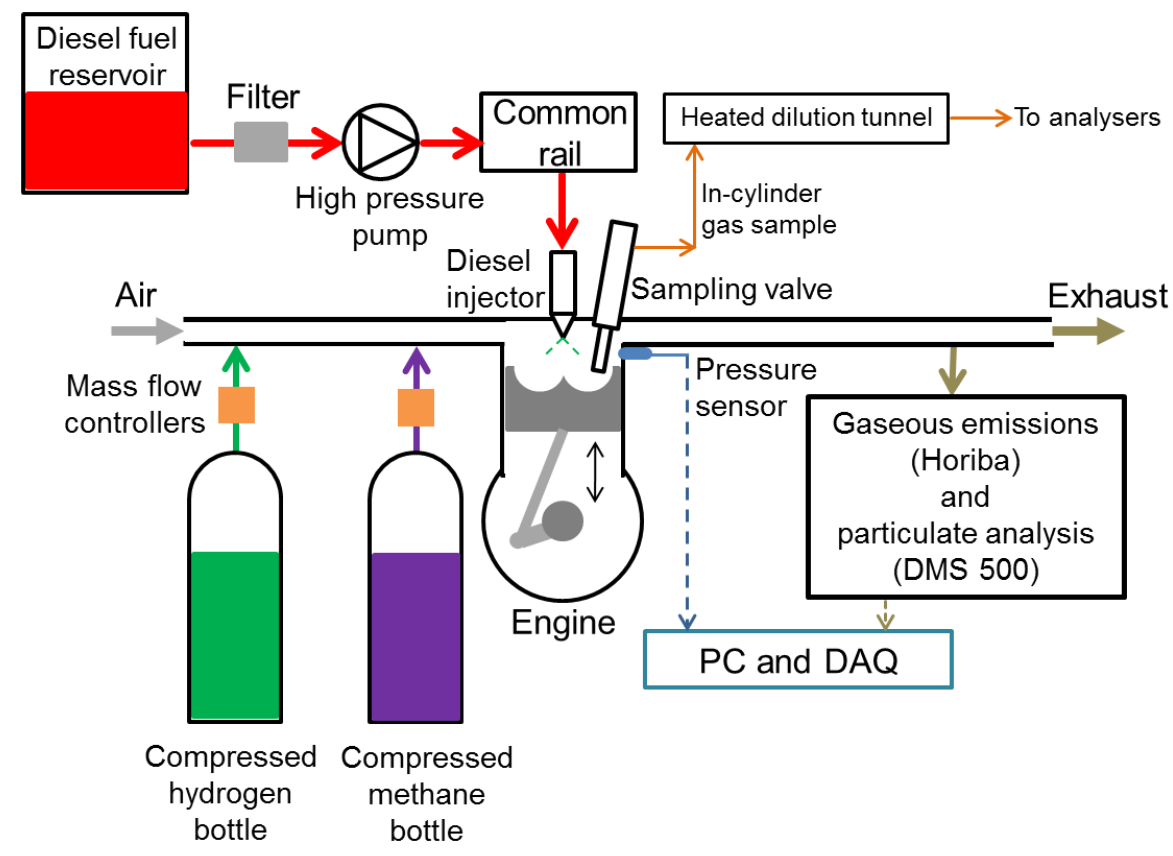

Figure 1: Schematic showing test engine arrangement including $\mathrm{CH}_{4}$ and $\mathrm{H}_{2}$ delivery and exhaust emissions instrumentation.

Table 1: Engine specifications

\begin{tabular}{|c|c|}
\hline Bore & $86 \mathrm{~mm}$ \\
\hline Stroke & $86 \mathrm{~mm}$ \\
\hline Swept volume & $499.56 \mathrm{~cm}^{3}$ \\
\hline Compression ratio (geometric) & $18.3: 1$ \\
\hline Maximum in-cylinder pressure & 150 bar \\
\hline Piston design & Central $\omega-$ bowl in piston \\
\hline Fuel injection pump & Delphi single-cam radial-piston pump \\
\hline High pressure common rail & Delphi solenoid controlled, 1600 bar max. \\
\hline Diesel fuel injector & Delphi DFI 1.3 6-hole solenoid valve \\
\hline Electronic fuel injection system & $1 \mu$ duration control \\
\hline Crank shaft encoder & 1800 ppr, 0.2 CAD resolution \\
\hline Oil and coolant temperature & $80 \pm 2.5^{\circ} \mathrm{C}$ \\
\hline
\end{tabular}




\subsection{In-cylinder gas sampling system}

The in-cylinder gas sampling system used in this study has been described in detail in Talibi et al. [32] and includes an electromagnetically actuated, fast-acting, poppet-type sampling valve and a heated dilution tunnel. Figure 2 shows a schematic of the sampling valve construction; it can be observed that the electromagnetic armature of sampling valve is not connected directly to the valve. This feature, based on the 'percussion' principle [32], allows shorter sampling durations $(<1 \mathrm{~ms})$, enabling the in-cylinder gas to be extracted from the combustion chamber during a very short window of a few crank angle degrees (CAD). When charged, the armature accelerates towards the valve stem, impacting it with a force large enough to open the poppet valve very briefly (period of order 6-10 CAD), allowing a small sample of in-cylinder gas to flow from the engine cylinder into the valve. The displacement of the poppet valve (of order 0-0.5 mm) was monitored with a sensitive Kaman LVDT (linear variable displacement transducer) sensor. The sampling valve was timed with the crank-shaft encoder (to a resolution of 0.2 CAD) and could therefore be opened at any desired crank angle in the engine cycle. The sampling valve was installed in the engine head, replacing one of the two inlet valves, with the valve tip penetrating $8 \mathrm{~mm}$ into the combustion chamber. Figure 3 shows the relative positions of the sampling valve and the diesel fuel injector inside the engine head with respect to the piston TDC position.

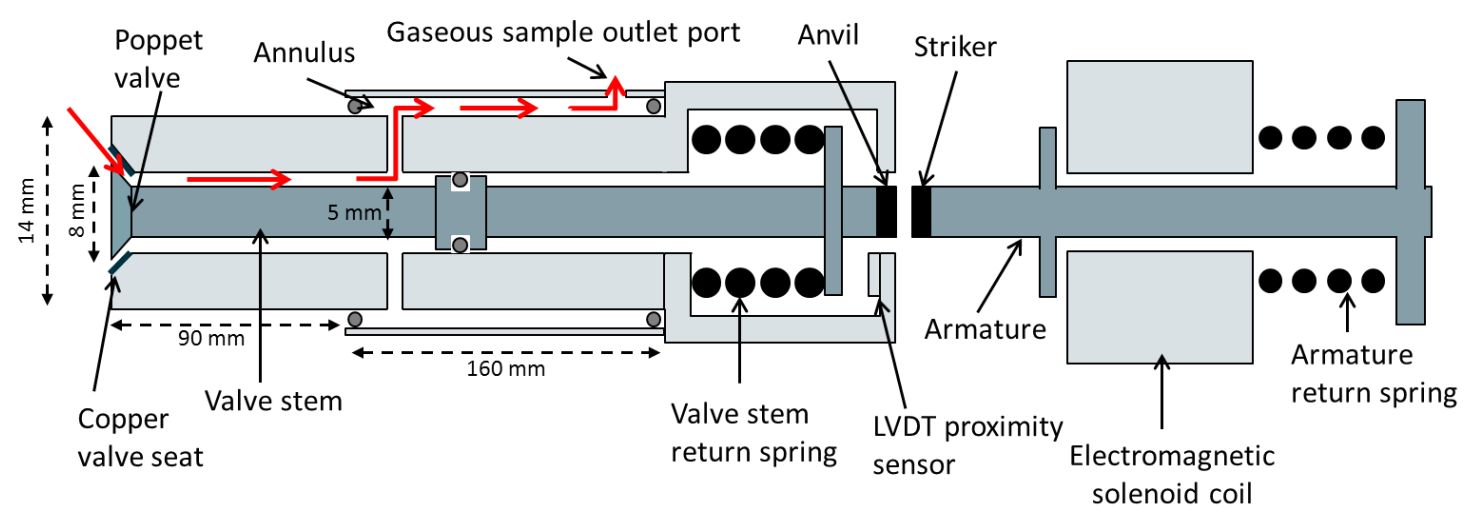

Figure 2: Schematic showing the internals of the in-cylinder sampling valve and the gas flow path from within the cylinder to the sample outlet port. 


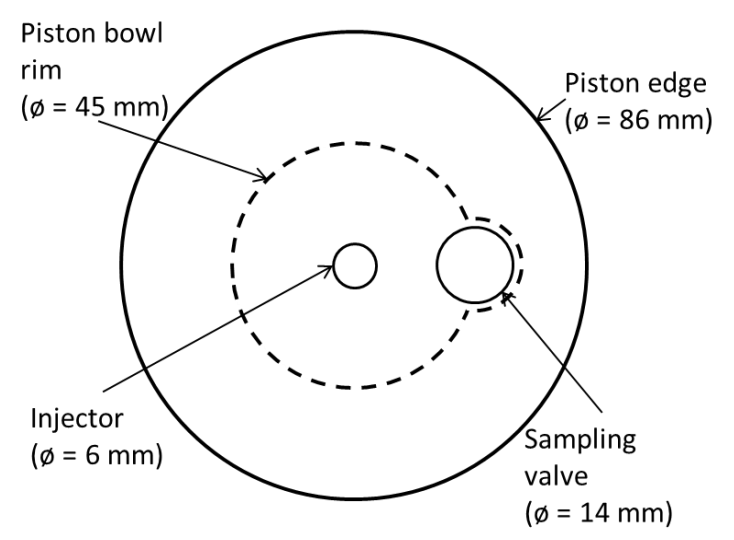

(a)

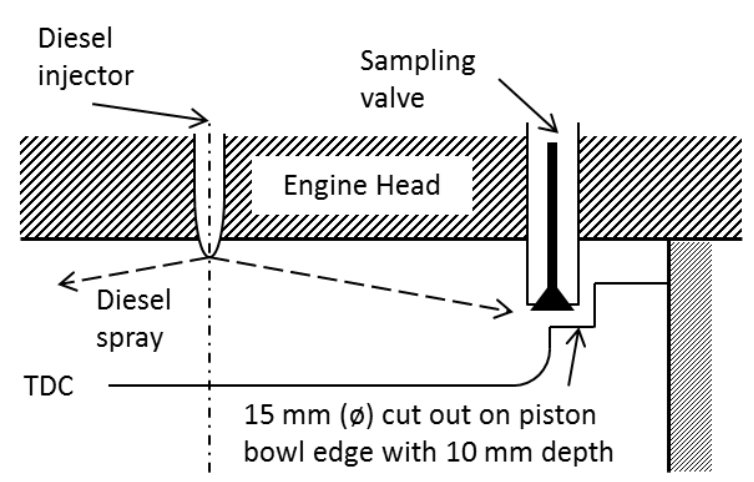

(b)

Figure 3: (a) plan view and (b) cross-sectional side view of the relative locations of the fuel injector and the sampling valve with respect to the piston at TDC.

The gas sample extracted using the sampling valve was fed to the heated dilution tunnel (maintained at $200^{\circ} \mathrm{C}$ ) which was used to buffer the gas samples and mix them with heated nitrogen gas (at $180^{\circ} \mathrm{C}$ ). This was done to increase the in-cylinder sample volume sufficiently so it could match the flow requirements of the Horiba emissions analyser rack. The molar $\mathrm{CO}_{2}$ concentrations of the undiluted and the $\mathrm{N}_{2}$-diluted in-cylinder gas samples were measured and used to calculate the degree of $\mathrm{N}_{2}$ dilution [32].

Flow calculations through the valve seat indicate that the combined reduction in temperature due to the gas expansion from cylinder gas pressure (40 to 100 bar) to the valve seat exit (at choked conditions) and heat transfer to the valve seat would result in a significant drop in temperature at the valve seat exit (of about 800-1200 K). Additionally, further irreversible expansion of the gas sample to near atmospheric pressure and heat transfer to the walls will occur as the sample travels through the cavity (annulus) that follows the valve seat. This substantially reduces the temperature of the extracted in-cylinder gas sample, hence slowing down reactions in the sample. Thus the composition of the sample gas measured by the analysers can be assumed to be representative of the stable species in the combustion chamber at the time of their extraction. 


\section{Experimental procedure and fuels used}

The tests reported in this paper were conducted at a common-rail fuel injection pressure of 900 bar, diesel fuel injection timing of 10 CAD BTDC and at an engine speed of $1200 \mathrm{rpm}$. The diesel fuel used for the tests had a cetane number of 53.2, carbon to hydrogen ratio of $6.32: 1$ by mass, with zero FAME (fatty acid methyl ester) content. Compressed hydrogen and methane gas of purity $99.995 \%$ and $99.5 \%$, respectively, were obtained from a commercial gas supplier (BOC).

\subsection{Experimental set 1: Exhaust emissions}

The first set of experiments consisted of fixing the flow rate of diesel fuel supplied to the engine (pilot diesel fuel flow rate), while varying the amount of $\mathrm{CH}_{4}-\mathrm{H}_{2}$ mixture being fed into the engine to vary the engine load. The fixed diesel fuel flow rate was used to ignite the aspirated $\mathrm{CH}_{4}-\mathrm{H}_{2}$ mixture, henceforth referred to as the pilot diesel fuel IMEP. Two series of tests were conducted and during the first series the pilot diesel fuel flow rate was kept fixed to achieve an engine load of 0 bar IMEP ( $270 \mu$ s diesel fuel injection duration, $1.40 \mathrm{ml} / \mathrm{min}$ ) from diesel fuel only (that is, without any $\mathrm{CH}_{4}$ or $\mathrm{H}_{2}$ being supplied to the engine). For a pilot diesel fuel only IMEP of 0 bar, no heat release could be discerned from the analysis of in-cylinder gas pressure. Therefore the diesel flow rate, equivalent to a pilot diesel IMEP of 0 bar, was taken to be minimum flow rate below which no spray emerges from the diesel injector nozzle. Nevertheless, the diesel flow rate, equivalent to a pilot diesel IMEP of 0 bar, was observed to be sufficient to ignite the aspirated $\mathrm{CH}_{4}-\mathrm{H}_{2}$-air mixture at all engine loads up to 7 bar IMEP (with low cycle-to-cycle variation in IMEP). During the second series of tests, the diesel pilot fuel flow rate was again kept fixed, but this time it was increased so that the engine developed a load of 1.5 bar IMEP ( $350 \mu$ s diesel fuel injection duration, $3.65 \mathrm{ml} / \mathrm{min}$ ) without any $\mathrm{CH}_{4}$ or $\mathrm{H}_{2}$ addition.

For each of the two pilot diesel fuel IMEPs of 0 and 1.5 bar, the above procedure was repeated for a variety of $\mathrm{CH}_{4}-\mathrm{H}_{2}$ mixture ratios, ranging from $20 \% \mathrm{CH}_{4}: 80 \% \mathrm{H}_{2}(\mathrm{v} / \mathrm{v})$ to $80 \% \mathrm{CH}_{4}: 20 \% \mathrm{H}_{2}(\mathrm{v} / \mathrm{v})$, as can be seen in Table 2; for each of the mixtures the flow rate was varied (with fixed pilot diesel fuel flow) to vary the engine load. It should be noted that increasing flow rates of the aspirated $\mathrm{CH}_{4}-\mathrm{H}_{2}$ mixture displaced some of the air induced by engine, thereby progressively reducing engine intake air flow with increasing engine load. Figure 4 shows the energy supplied to the engine from the $\mathrm{H}_{2}$ as a function of the total energy $\left(\mathrm{CH}_{4}-\mathrm{H}_{2}\right.$ mixture plus diesel) supplied to the engine and the percentage of $\mathrm{O}_{2}$ in the intake charge, for the two pilot diesel fuel IMEPs of 0 bar and 1.5 bar, at various engine loads and $\mathrm{CH}_{4}-\mathrm{H}_{2}$ mixture ratios. Table 3 lists the properties of diesel fuel, methane and hydrogen used in these experiments $[1,33,34]$. 
An additional series of baseline (control) tests were carried out, for comparison, using diesel fuel only (without any $\mathrm{CH}_{4}$ or $\mathrm{H}_{2}$ ), with the diesel fuel injection period being varied to change the engine load between 0 and 7 bar IMEP.

\begin{tabular}{|c|c|c|c|c|c|c|c|}
\hline $\begin{array}{c}\text { Pilot } \\
\text { diesel } \\
\text { (bar IMEP) }\end{array}$ & $\begin{array}{l}\text { Diesel } \\
\text { fuel flow } \\
\text { rate } \\
\text { (ml/min) }\end{array}$ & $\begin{array}{c}\mathrm{CH}_{4}: \mathrm{H}_{2} \\
\text { mixture } \\
\text { ratio } \\
(\mathrm{v} / \mathrm{v})\end{array}$ & $\begin{array}{c}\mathrm{CH}_{4} \text { flow } \\
\text { rate } \\
\text { (l/min) }\end{array}$ & $\begin{array}{l}\mathrm{H}_{2} \text { flow } \\
\text { rate } \\
(\mathrm{I} / \mathrm{min})\end{array}$ & $\begin{array}{c}\mathrm{CH}_{4} \text {-air } \\
\text { equivalence } \\
\text { ratio }\left(\phi_{\mathrm{CH} 4}\right)\end{array}$ & $\begin{array}{c}\mathrm{H}_{2} \text {-air } \\
\text { equivalence } \\
\text { ratio }\left(\phi_{\mathrm{H}_{2}}\right)\end{array}$ & $\begin{array}{c}\text { Engine } \\
\text { IMEP } \\
\text { (bar) }\end{array}$ \\
\hline \multirow{5}{*}{0} & \multirow{5}{*}{1.40} & $80: 20$ & $4.8-12.1$ & $1.2-3.0$ & $0.19-0.50$ & $0.01-0.03$ & \multirow{5}{*}{$0-7$} \\
\hline & & $60: 40$ & $4.2-10.8$ & $2.7-7.2$ & $0.16-0.45$ & $0.03-0.07$ & \\
\hline & & $50: 50$ & $3.7-9.8$ & $3.7-9.8$ & $0.15-0.40$ & $0.03-0.09$ & \\
\hline & & $40: 60$ & $3.2-9.0$ & $4.8-13.5$ & $0.13-0.38$ & $0.04-0.13$ & \\
\hline & & $20: 80$ & $2.0-6.0$ & $7.8-24.2$ & $0.08-0.26$ & $0.07-0.24$ & \\
\hline \multirow{5}{*}{1.5} & \multirow{5}{*}{3.65} & $80: 20$ & $1.6-10.2$ & $0.0-2.1$ & $0.06-0.41$ & $0.000-0.02$ & \multirow{5}{*}{$1.5-7$} \\
\hline & & $60: 40$ & $1.0-8.9$ & $0.6-6.0$ & $0.04-0.36$ & $0.005-0.06$ & \\
\hline & & $50: 50$ & $1.0-8.5$ & $1.0-8.5$ & $0.04-0.35$ & $0.009-0.08$ & \\
\hline & & $40: 60$ & $1.0-7.6$ & $1.5-11.4$ & $0.04-0.31$ & $0.010-0.10$ & \\
\hline & & $20: 80$ & $0.6-5.0$ & $2.5-20.0$ & $0.02-0.21$ & $0.022-0.20$ & \\
\hline
\end{tabular}

Table 2: Test parameter matrix for the exhaust emission experiments

\begin{tabular}{|c|c|c|c|}
\hline Property & Diesel fuel & Hydrogen & Methane \\
\hline Density $\left(\mathrm{kg} / \mathrm{m}^{3}\right)$ & 831.9 & 0.0838 & 0.66 \\
\hline $\begin{array}{c}\text { Lower heating } \\
\text { value (MJ/kg) }\end{array}$ & 43.14 & 120 & 50 \\
\hline $\begin{array}{c}\text { Laminar flame } \\
\text { speed (cm/s) }\end{array}$ & $5-80$ & 230 & 42 \\
\hline $\begin{array}{c}\text { Flammability } \\
\text { range } \\
\text { (\% v/v in air) }\end{array}$ & $0.6-7.5$ & $4-76$ & $4.4-15$ \\
\hline
\end{tabular}

Table 3: Properties of diesel fuel, hydrogen and methane at $1 \mathrm{~atm}$ and $300 \mathrm{~K}[1,29,30]$ 


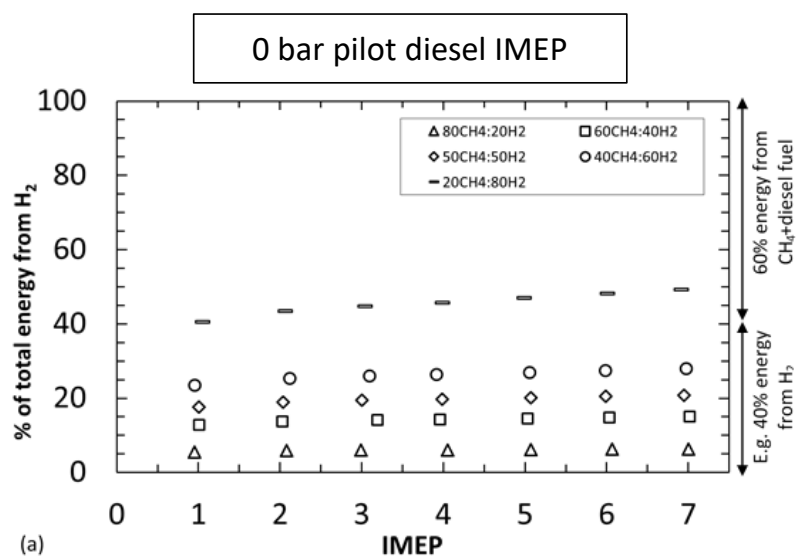

(a)

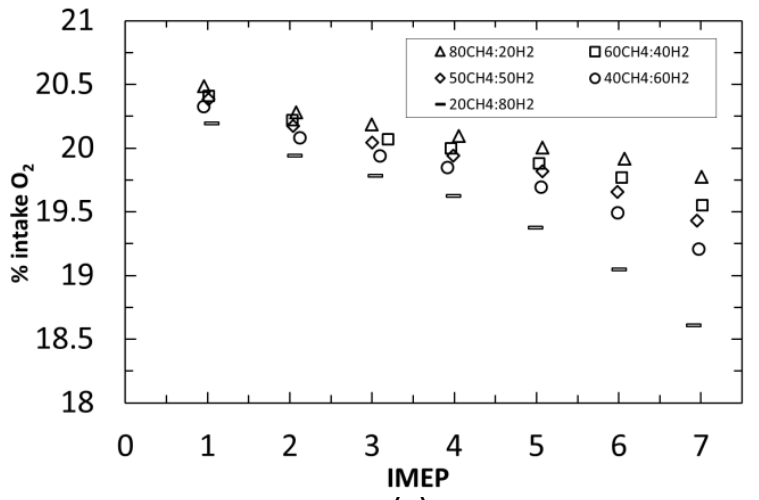

(c)

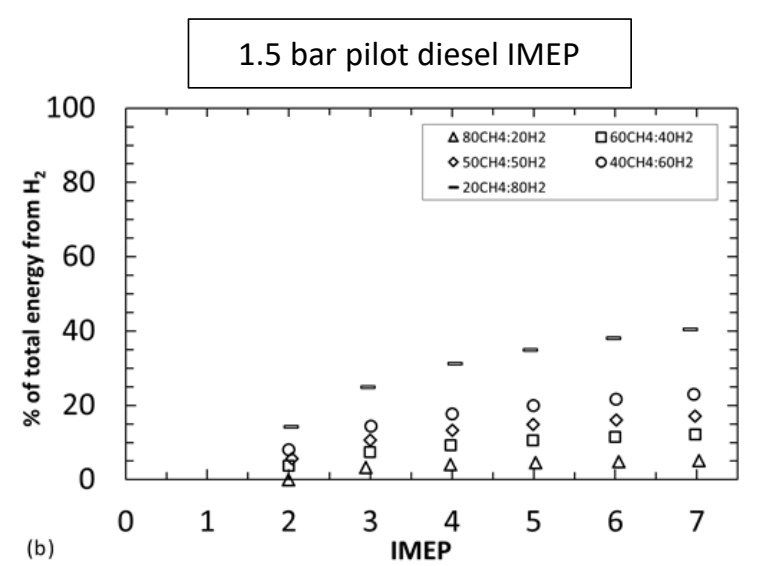

(b)

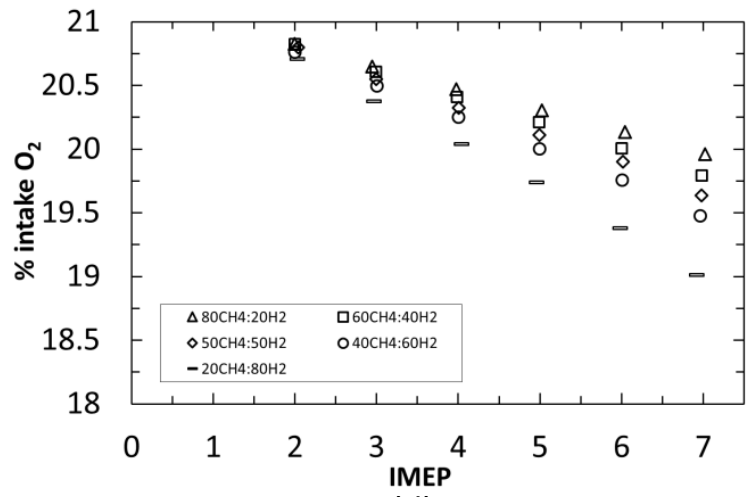

(d)

Figure 4: (a) and (b) \% input energy from $\mathrm{H}_{2}$, and (c) and (d) \% intake $\mathrm{O}_{2}$ for two pilots diesel fuel IMEPs, at various engine loads (IMEP) and $\mathrm{CH}_{4}-\mathrm{H}_{2}$ mixture ratios.

\subsection{Experimental set 2: In-cylinder gas sampling}

A second set of experiments was conducted using the sampling system to extract gas samples from the engine cylinder; the pilot diesel fuel flow rate was fixed so as to provide an engine load of $1.5 \mathrm{bar}$ IMEP. At an engine load of 1.5 bar IMEP, and with no $\mathrm{CH}_{4}$ or $\mathrm{H}_{2}$ addition, the measured $\mathrm{NO}_{x}$ concentrations were observed to be negligible. Therefore, when the $\mathrm{CH}_{4}-\mathrm{H}_{2}$ mixture was added in the course of the in-cylinder sampling experiments to increase the engine load, it was assumed that any observed $\mathrm{NO}_{x}$ could be primarily attributed to the presence of the $\mathrm{CH}_{4}$ and $\mathrm{H}_{2}$.

The tests were conducted at a constant overall engine load of 4 bar IMEP, with the pilot diesel fuel contributing 1.5 bar of the total engine IMEP and the $\mathrm{CH}_{4}-\mathrm{H}_{2}$ mixture supplying the balance of 2.5 bar IMEP. Two $\mathrm{CH}_{4}-\mathrm{H}_{2}$ mixture ratios of $20 \% \mathrm{CH}_{4}: 80 \% \mathrm{H}_{2}(\mathrm{v} / \mathrm{v})$ and $80 \% \mathrm{CH}_{4}: 20 \% \mathrm{H}_{2}(\mathrm{v} / \mathrm{v})$ were utilised so as to provide a significant contrast between the in-cylinder gas composition obtained from the two series of experiments. Gas samples were extracted from the combustion cylinder using two different sampling arrangements, relative to one of the diesel fuel spray plumes, as can be seen in Figure 5. With the first arrangement, gas samples were collected from a region of high diesel fuel 
concentration within the core of one of the diesel fuel spray plumes, while with the second arrangement samples were collected from an area of relatively low diesel fuel concentration between two fuel spray plumes. Since the sampling valve could not be spatially moved in the engine head, the change in the sampling arrangement was achieved by rotating of the centrally-located injector. Prior to the in-cylinder gas sampling tests, the positions of the fuel spray core and its boundary were experimentally determined by rotating the diesel fuel injector in small steps and measuring the levels of unburned hydrocarbons in the in-cylinder gas sample at each injector rotation. This methodology allowed approximate fuel spray boundaries to be sketched, shown by means of broken lines in Figure 5.

For each of the two relative sampling arrangements shown in Figure 5, gas samples were extracted at a number of sampling timings in the engine cycle, from 20 CAD BTDC to 100 CAD ATDC in incremental crank angle steps ranging between 10 and 20 CAD. This allowed in-cylinder gas samples to be obtained at various stages of the combustion cycle; from before diesel fuel injection, through the ignition delay period, the premixed burn stage and the early and late diffusion burn stages.

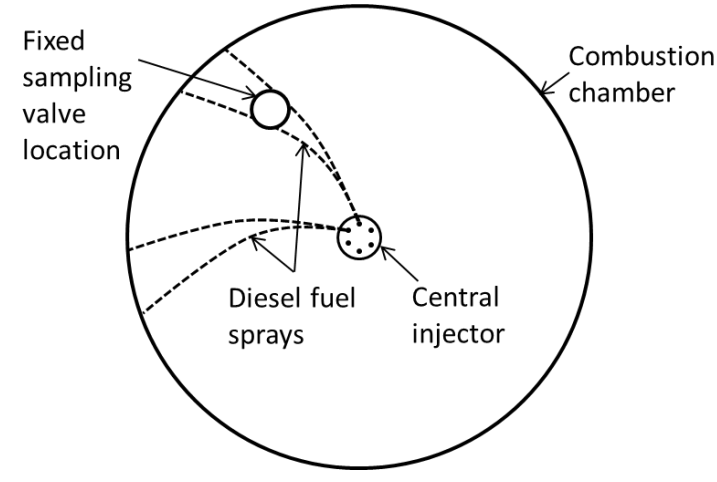

(a)

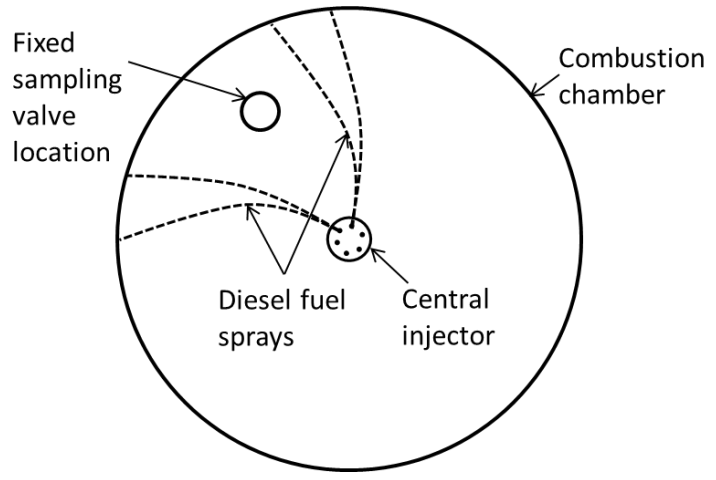

(b)

Figure 5: Schematic showing the two sampling arrangements (a) and (b) achieved by the rotation of the centrally located injector. 


\section{Results and discussion}

\subsection{Combustion characteristics}

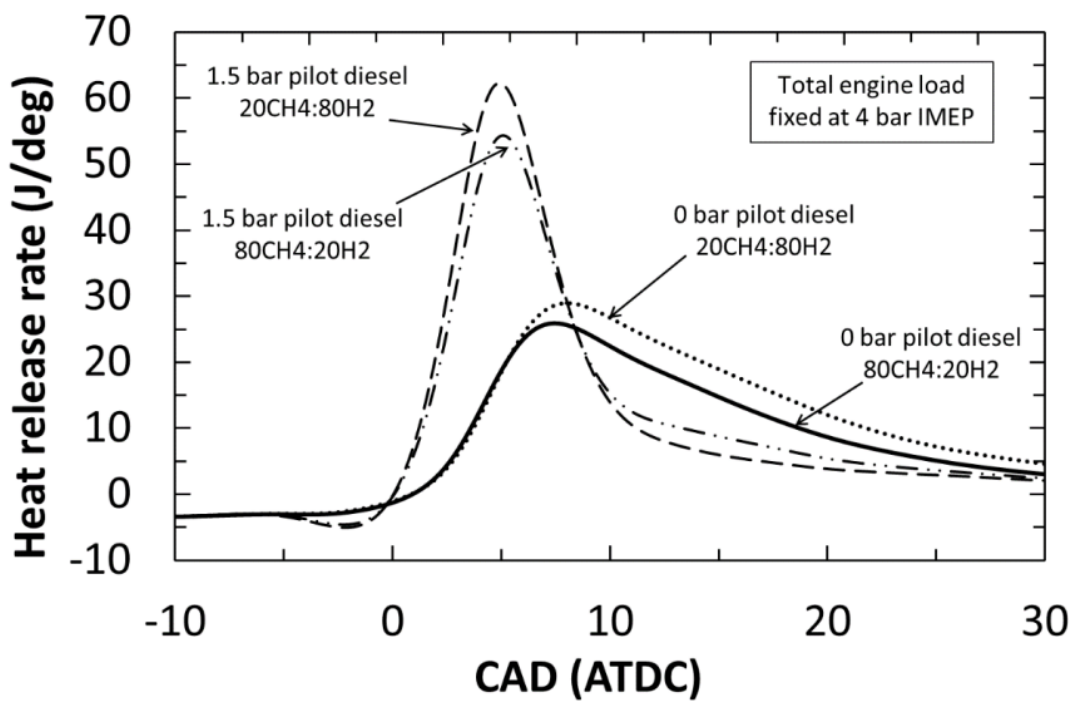

Figure 6: Heat release rate curves for a fixed engine load of 4 bar IMEP, at two pilot diesel fuel IMEPs and for two $\mathrm{CH}_{4}-\mathrm{H}_{2}$ mixture proportions.

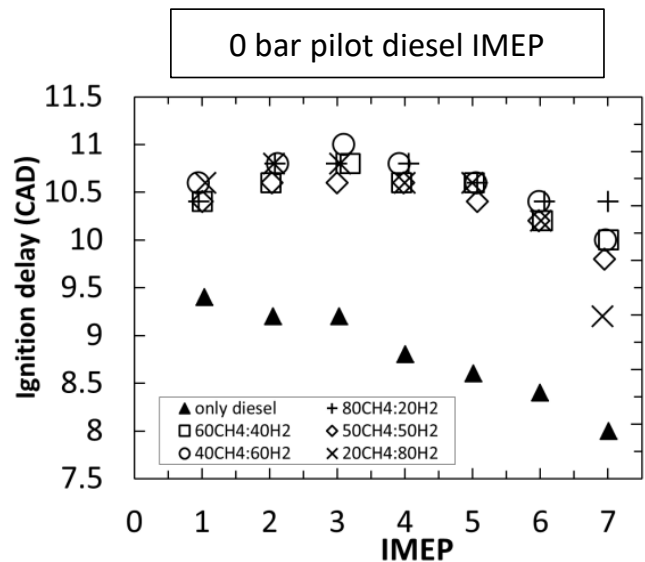

(a)

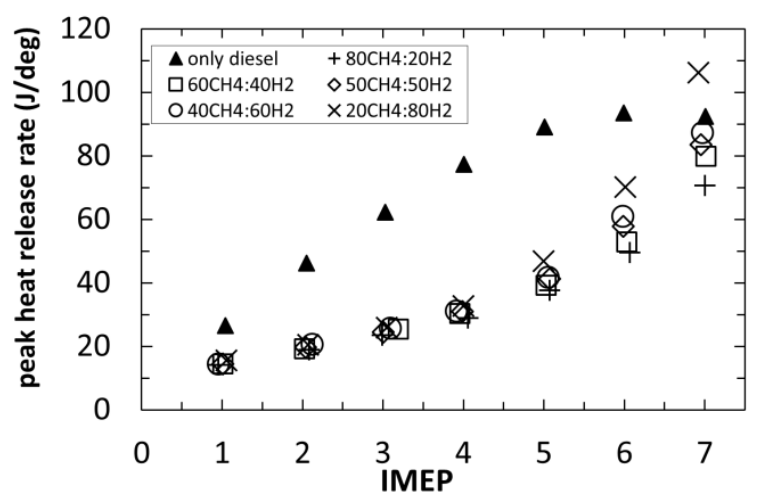

(c)

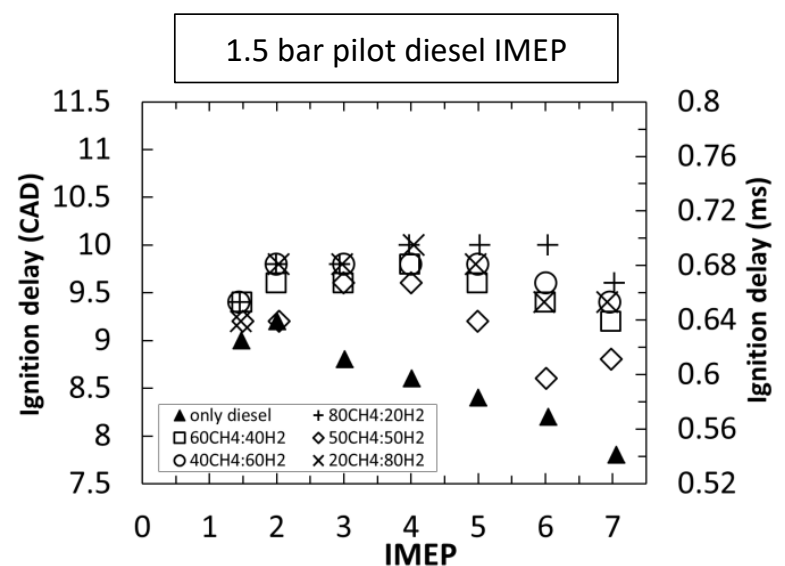

(b)

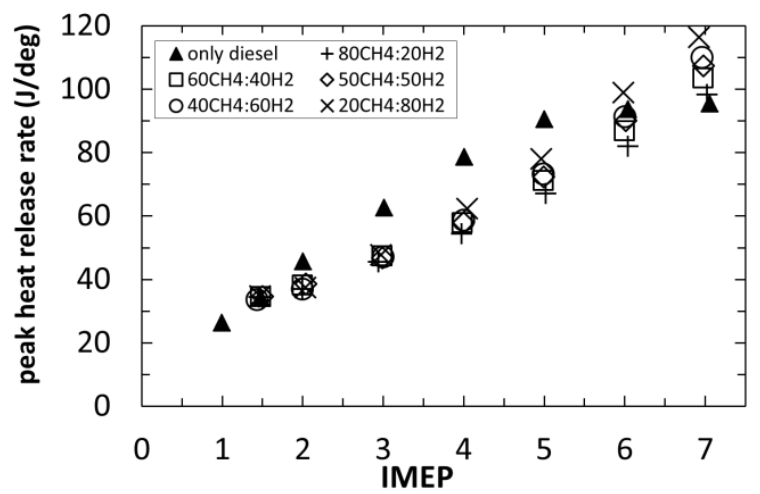

(d)

Figure 7: (a) and (b) Duration of ignition delay, and (c) and (d) peak heat release rates for the two pilot diesel fuel IMEPs and with various $\mathrm{CH}_{4}-\mathrm{H}_{2}$ mixture proportions. 
Figure 6 shows the heat release rate curves for the two pilot diesel fuel IMEPs of 0 bar and 1.5 bar, while supplying the engine with two different $\mathrm{CH}_{4}-\mathrm{H}_{2}$ mixture ratios of $20 \% \mathrm{CH}_{4}: 80 \% \mathrm{H}_{2}(\mathrm{v} / \mathrm{v})$ and $80 \% \mathrm{CH}_{4}: 20 \% \mathrm{H}_{2}(\mathrm{v} / \mathrm{v})$ to achieve the required total engine load of 4 bar IMEP (that is, including the pilot diesel fuel IMEP). Comparing the heat release rate curves at the two pilot diesel IMEP conditions ( 0 bar and 1.5 bar), it can be seen that the rate of increase of heat release post ignition is considerably faster in the case of 1.5 bar pilot diesel fuel IMEP, leading to higher peak heat release rates closer to engine TDC. This is because at the higher pilot diesel IMEP of 1.5 bar, significantly more diesel is injected into the combustion chamber (Table 2 shows the diesel fuel flow rates), and hence an appreciable amount of diesel fuel-air mixture is already premixed and prepared during the delay period, and combusts rapidly once ignition has occurred [35]. It can also be speculated that the larger volume of pilot diesel fuel being injected at 1.5 bar IMEP (as compared to 0 bar pilot diesel fuel IMEP) increases the number of ignition sites available for $\mathrm{CH}_{4}$ and $\mathrm{H}_{2}$ combustion, which along with diesel fuel combustion results in a larger proportion of energy being released closer to TDC, and hence higher peak heat release rates.

Now considering the heat release rate curves for the two $\mathrm{CH}_{4}-\mathrm{H}_{2}$ mixture proportions at the same pilot diesel IMEP of 1.5 bar, the peak heat release rate for a mixture ratio of $20 \mathrm{CH}_{4}: 80 \mathrm{H}_{2}$ is higher as compared to that for $80 \mathrm{CH}_{4}: 20 \mathrm{H}_{2}$, despite the ignition delay period being similar in both cases (Figure 6). This could be attributed to $\mathrm{H}_{2}$ having a significantly lower ignition energy requirement as compared to $\mathrm{CH}_{4}$ [3], which would result in the $\mathrm{H}_{2}$ being consumed quite quickly and leading to greater amount of energy release between 0 and 10 CAD ATDC when combusting the $\mathrm{H}_{2}$-rich $20 \mathrm{CH}_{4}: 80 \mathrm{H}_{2}$ mixture. Beyond $10 \mathrm{CAD}$ ATDC, as the $\mathrm{H}_{2}$ becomes consumed, the heat release rate for the $20 \mathrm{CH}_{4}: 80 \mathrm{H}_{2}$ drops below that of the $80 \mathrm{CH}_{4}: 2 \mathrm{OH}_{2}$.

Figure 7 shows the ignition delay period and the peak heat release rates for the two pilot diesel fuel IMEPs of 0 bar and 1.5 bar, at a variety of engine loads and $\mathrm{CH}_{4}-\mathrm{H}_{2}$ mixture proportions. For comparison purposes, Figure 7 also shows the ignition delay and peak heat release rates when the engine load is increased without any $\mathrm{CH}_{4}$ or $\mathrm{H}_{2}$ addition, that is, by merely increasing the amount of diesel fuel injected. Ignition delay is defined here as the duration in CAD between the start of diesel fuel injection (SOI) and the start of combustion (SOC). SOI is taken to be the time when the actuation signal is sent to the injector, whereas the SOC is defined as the first incidence of detectable heat release following autoignition of the diesel fuel. The increase in IMEP, above the pilot diesel fuel IMEP, is achieved by delivering increasing amounts of $\mathrm{CH}_{4}-\mathrm{H}_{2}$ mixtures to the engine. The most apparent feature in Figure 7 is the considerably longer ignition delay with $\mathrm{CH}_{4}-\mathrm{H}_{2}$ mixtures as 
compared to diesel only fuelling. It could be speculated that at the relatively low temperatures prevalent in-cylinder during ignition conditions, the $\mathrm{CH}_{4}$ and $\mathrm{H}_{2}$ remain intact and do not participate in the low temperature reactions leading to ignition; it may be suggested that they might even hamper the process by diluting the intake $\mathrm{O}_{2}$ and hindering oxidation reactions that lead to ignition.

For a pilot diesel fuel IMEP of 0 bar, the ignition delay period at the various engine loads is quite similar between the different $\mathrm{CH}_{4}-\mathrm{H}_{2}$ mixtures, with the only exception being at 7 bar IMEP where the ignition delay period decreases as the proportion of $\mathrm{H}_{2}$ in the $\mathrm{CH}_{4}-\mathrm{H}_{2}$ mixture increases. For a pilot diesel IMEP of 1.5 bar, differences in the ignition delay period between the various $\mathrm{CH}_{4}-\mathrm{H}_{2}$ mixtures can be observed above an engine load of 4 bar IMEP, whereby the ignition delay period initially decreases as the mixture proportion changes from $80 \mathrm{CH}_{4}: 20 \mathrm{H}_{2}$ to $50 \mathrm{CH}_{4}: 50 \mathrm{H}_{2}$, but then subsequently increases as the $\mathrm{CH}_{4}$ is further substituted by $\mathrm{H}_{2}$ (Figure 7).

It can be observed from Figure 7 that the ignition delay period is shorter for the higher pilot diesel IMEP of 1.5 bar, as compared to 0 bar, for all test points. This is expected and can be attributed to the larger amount of diesel fuel being injected into the cylinder to achieve a 1.5 bar pilot diesel fuel IMEP. Diesel fuel is expected to ignite in near-stoichiometric pockets of fuel and air which increases local gas temperatures to about $2200 \mathrm{~K}$ [35]. A larger amount of diesel fuel igniting at the start of combustion results in a larger preheating effect of the intake charge; preliminary calculations indicate that the in-cylinder gas temperatures post diesel combustion would be $250-300 \mathrm{~K}$ higher for a pilot diesel IMEP of 1.5 bar as compared to 0 bar. The higher pilot diesel IMEP also means that the diesel fuel is injected for longer into the cylinder and a higher number of sites are available (post diesel ignition) for the ignition of the aspirated $\mathrm{CH}_{4}-\mathrm{H}_{2}$ mixture. This results in higher rates of increase of heat release and higher peak heat release rates, as can be observed in Figure 6.

For both the pilot diesel IMEPs of 0 and 1.5 bar IMEP, it can be seen from Figure 7 that for each $\mathrm{CH}_{4^{-}}$ $\mathrm{H}_{2}$ mixture, there is a general trend of an initial increase and then a subsequent decrease in ignition delay as the amount $\mathrm{CH}_{4}-\mathrm{H}_{2}$ mixture being supplied is increased (moving from left to right). Similar trends in ignition delay were also observed by the author when combusting $\mathrm{H}_{2}$-diesel fuel mixtures [31]. The initial increase in ignition delay could be attributed to a reduction in intake $\mathrm{O}_{2}$ (as it displaced by $\mathrm{CH}_{4}$ and $\mathrm{H}_{2}$ ), leading to a decrease in low temperature fuel breakdown reactions and delaying autoignition [35-37]. At engine loads higher than 3-4 bar IMEP, the ignition delay period decreased; this is believed to be due to elevated in-cylinder temperatures arising from higher engine loads. The peak heat release rates for each of the pilot diesel IMEPs, at all engine loads and $\mathrm{CH}_{4}-\mathrm{H}_{2}$ mixture proportions are quite similar except for the peak heat release rates for the $20 \mathrm{CH}_{4}: 80 \mathrm{H}_{2}$ mixture ratio at 0 bar pilot diesel IMEP, which shows an almost exponential increase in peak heat 
release rates at engine loads above 4 bar IMEP. This is likely due to the increasing proportion of $\mathrm{H}_{2}$ in the in-cylinder gas mixture, resulting in smaller ignition delay periods and higher gas temperatures achieved post combustion.

\section{2. $\quad \mathrm{CO}_{2}, \mathrm{CO}$ and unburned THC exhaust gas emissions}

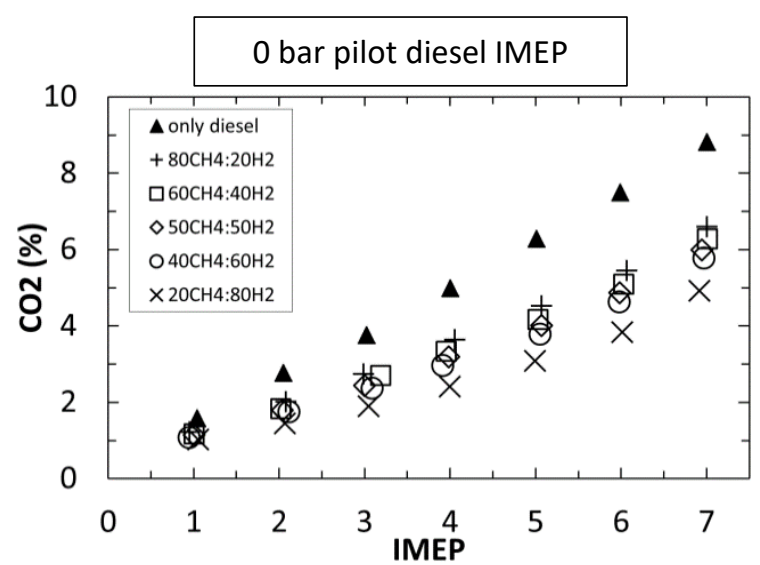

(a)

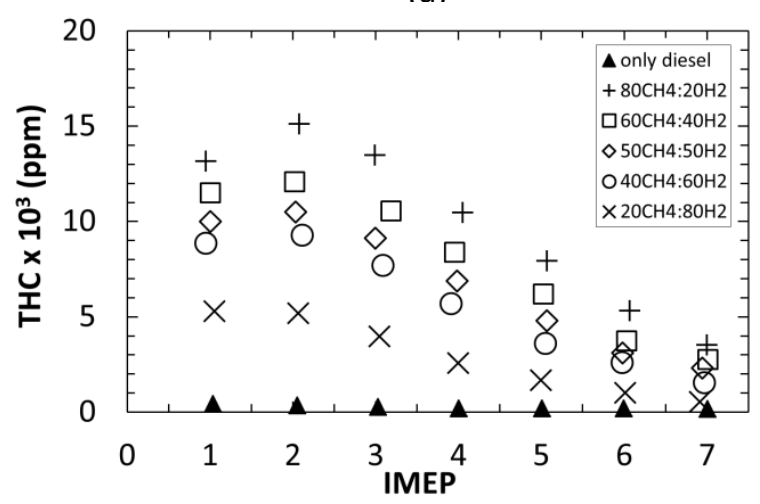

(c)

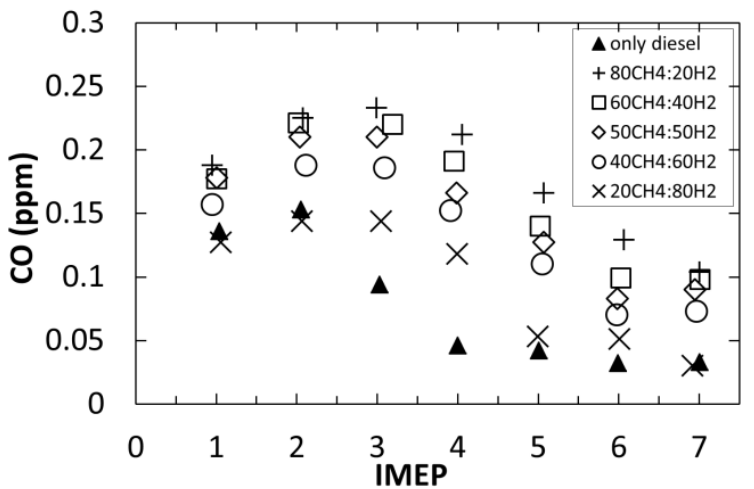

(e)

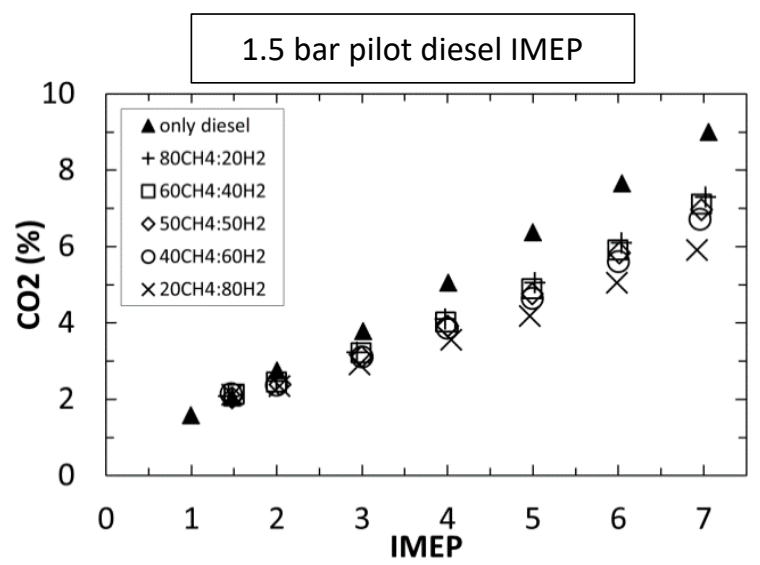

(b)

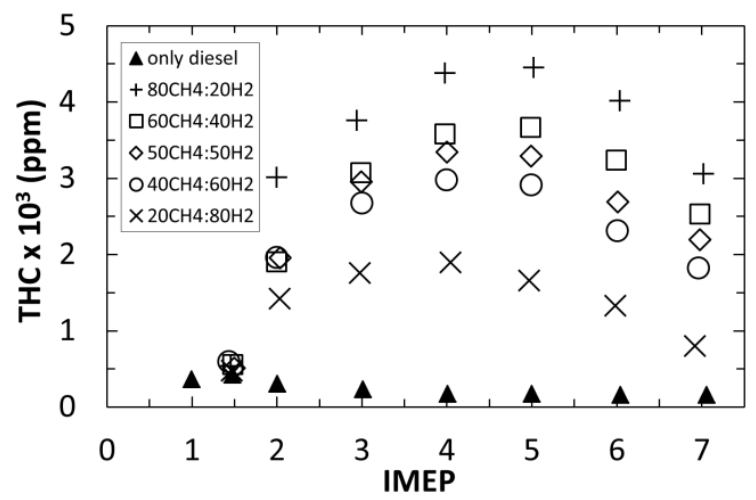

(d)

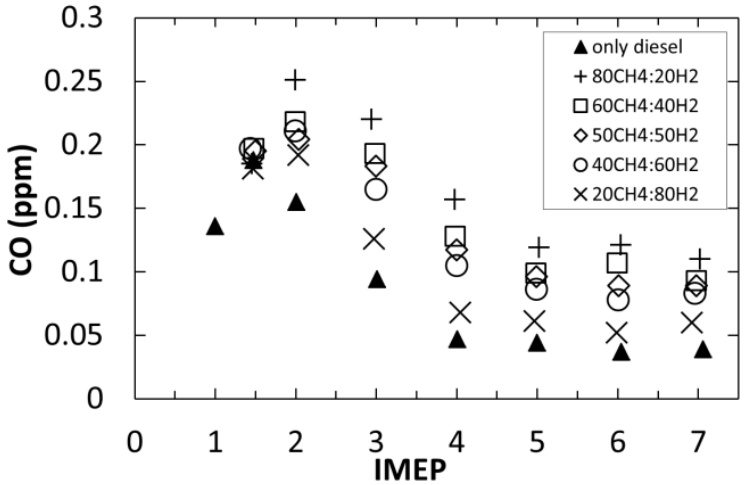

(f)

Figure 8: Exhaust emissions of (a) carbon dioxide $\left(\mathrm{CO}_{2}\right)$, (b) unburned total hydrocarbons (THC) and (c) carbon monoxide (CO) for the two pilot diesel fuel IMEPs, and for various $\mathrm{CH}_{4}-\mathrm{H}_{2}$ mixture proportions.

Figure 8 shows the gaseous exhaust emissions of $\mathrm{CO}_{2}$, unburned total hydrocarbons (THC) and $\mathrm{CO}$ for the two pilot diesel fuel IMEPs of 0 bar and 1.5 bar, at various engine loads and $\mathrm{CH}_{4}-\mathrm{H}_{2}$ mixture proportions. For both pilot diesel IMEPs and at all $\mathrm{CH}_{4}-\mathrm{H}_{2}$ mixture proportions, an almost linear increase in $\mathrm{CO}_{2}$ emissions is observed as the amount of $\mathrm{CH}_{4}-\mathrm{H}_{2}$ mixture being supplied to the engine 
is increased in order to increase the engine load. Comparing $\mathrm{CO}_{2}$ emissions between different $\mathrm{CH}_{4}-\mathrm{H}_{2}$ mixture proportions, as expected, the $\mathrm{CH}_{4}-\mathrm{H}_{2}$ mixtures with a higher proportion of $\mathrm{H}_{2}$ produce relatively less $\mathrm{CO}_{2}$ from combustion. Figure 8 also shows the exhaust emissions of $\mathrm{CO}_{2}$, unburned THC and $\mathrm{CO}$ when the engine load is increased without any $\mathrm{CH}_{4}$ or $\mathrm{H}_{2}$ addition, that is, by merely increasing the amount of diesel fuel injected. It is important to note from Figure 8 that at all engine loads, the $\mathrm{CO}_{2}$ emissions when combusting $\mathrm{CH}_{4}-\mathrm{H}_{2}$ mixtures (plus the pilot diesel fuel) are considerably lower compared to when burning only diesel fuel to develop the same engine load. This is due to $\mathrm{CH}_{4}$ having a lower carbon to hydrogen ratio as compared to diesel fuel, and hence resulting in lower $\mathrm{CO}_{2}$ emissions.

Now considering the unburned THC and CO emissions, for both pilot diesel IMEPs of 0 bar and 1.5 bar, it can be seen from Figure 8 that for each $\mathrm{CH}_{4}-\mathrm{H}_{2}$ mixture, as the engine load is increased (by increasing the supply of $\mathrm{CH}_{4}-\mathrm{H}_{2}$ mixture to the engine), there is a general trend of an initial increase in THC and $\mathrm{CO}$ emissions followed by a subsequent decrease. The initial increase in unburned THC and $\mathrm{CO}$ emissions at engine loads of below 4 bar IMEP could most likely be attributed to the lean incylinder $\mathrm{CH}_{4}$-air and $\mathrm{H}_{2}$-air mixture stoichiometry, leading to increased quenching of the $\mathrm{CH}_{4}$ flame front. It is possible that below 4 bar IMEP, the generated flame front may not be able to sustain itself to consume all the aspirated $\mathrm{CH}_{4}$, resulting in considerable amounts of unburned $\mathrm{CH}_{4}$ passing into the exhaust (despite the in-cylinder $\mathrm{CH}_{4}$-air stoichiometry becoming less lean with increasing load). As the engine load is increased above 4 bar IMEP, by aspirating a greater volume of $\mathrm{CH}_{4}-\mathrm{H}_{2}$ mixture, the residual in-cylinder gas temperatures become sufficient to improve $\mathrm{CH}_{4}$ oxidation rates and, therefore, result in lower unburned THC and CO emissions.

Comparing the unburned THC emissions between the two pilot diesel fuel flow rates, it can be observed from Figures 8 (c) and (d), that THC emissions are significantly lower (by a factor of 4 in some cases) for the higher pilot diesel fuel IMEP. As discussed earlier, this can be attributed to the higher preheating effect of the intake charge due to the larger volume of diesel fuel being injected into the cylinder. This leads to a larger number of near-stoichiometric pockets of diesel fuel-air mixture available for combustion following the ignition delay period and a greater number of sites for ignition of the aspirated $\mathrm{CH}_{4}$ post ignition. In addition, the higher in-cylinder gas temperatures due to the larger volume of diesel fuel combusting inside the chamber (in the case of 1.5 bar pilot diesel IMEP as compared to 0 bar) promoted the oxidation of hydrocarbons. 


\section{3. $\quad \mathrm{NO}_{\mathrm{x}}$ exhaust gas emissions}

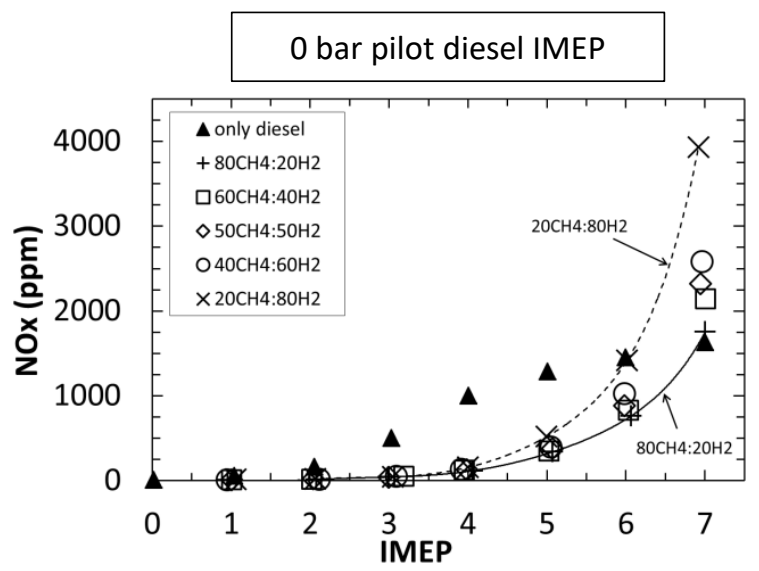

(a)

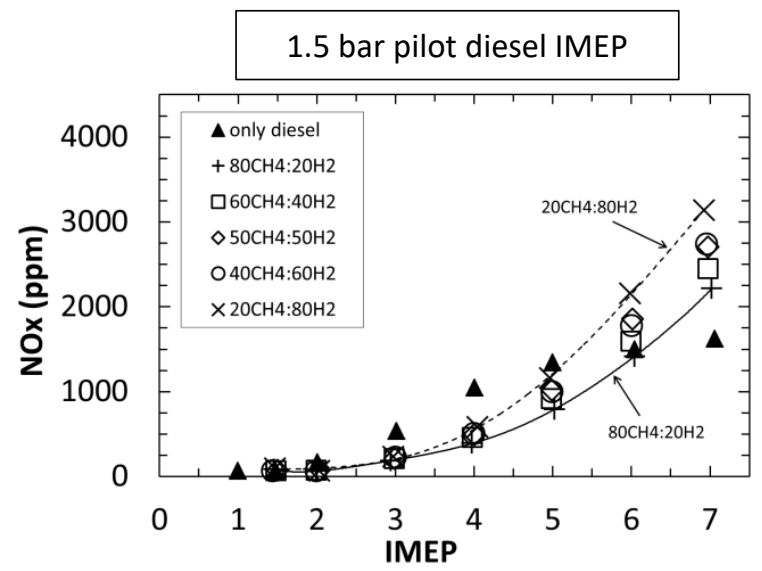

(b)

Figure 9: Variation in the exhaust emissions of oxides of nitrogen $\left(\mathrm{NO}_{\mathrm{x}}\right)$ for the two pilot diesel fuel IMEPs, at various engine loads and $\mathrm{CH}_{4}-\mathrm{H}_{2}$ mixture proportions

Figure 9 shows the gaseous exhaust emissions of $\mathrm{NO}_{x}$ for the two pilot diesel fuel IMEPs of 0 bar and 1.5 bar, at various engine loads and $\mathrm{CH}_{4}-\mathrm{H}_{2}$ mixture proportions. Considering the tests carried out with a pilot diesel fuel IMEP of 0 bar, it can be seen from Figure 9 that at low engine loads, below 4 bar IMEP, NO $\mathrm{N}_{\mathrm{x}}$ emission levels are low (<100 ppm). However, above 4 bar IMEP, NO levels in the exhaust gas rise steeply with increasing engine load. These results are comparable to the $\mathrm{NO}_{\mathrm{x}}$ exhaust emission results obtained with $\mathrm{H}_{2}$-diesel fuel co-combustion [31], whereby $\mathrm{NO}_{\mathrm{x}}$ emissions significantly increased when the engine load rose above 4 bar IMEP. The adiabatic flame temperatures at the various in-cylinder $\mathrm{H}_{2}$-air equivalence ratios were calculated, and it was observed that above 4 bar IMEP, the temperatures crossed the threshold (1600K) for rapid thermal $\mathrm{NO}_{x}$ formation [31].

Now considering Figure 9, at engine loads lower than 4 bar IMEP, the temperatures resulting from the combustion of the very lean in-cylinder $\mathrm{CH}_{4}$-air and $\mathrm{H}_{2}$-air mixtures $\left(\phi_{\mathrm{H} 2}=0.02\right.$ and $\phi_{\mathrm{CH}_{4}}=0.35$ at $80 \mathrm{CH}_{4}: 20 \mathrm{H}_{2}$ at an engine load of 4 bar IMEP) are below the rapid $\mathrm{NO}_{x}$ production threshold temperature $[35,38]$. However, as the $\mathrm{CH}_{4}-\mathrm{H}_{2}$ mixture being supplied to the engine is increased, to increase the engine load above 4 bar IMEP, the in-cylinder mixture concentration becomes sufficient for the post combustion gas temperatures to go above the level at which $\mathrm{NO}_{\mathrm{x}}$ formation rates accelerate significantly. This exponential increase in $\mathrm{NO}_{x}$ production rates is expected as the incylinder $\mathrm{CH}_{4} / \mathrm{H}_{2}$-air mixture becomes less lean, and is consistent with the extended Zeldovich $\mathrm{NO}_{x}$ formation mechanism [39]. Comparing the $\mathrm{NO}_{x}$ emissions from the $20 \mathrm{CH}_{4}: 80 \mathrm{H}_{2}$ and $80 \mathrm{CH}_{4}: 20 \mathrm{H}_{2}$ mixtures, it can be observed from Figure 9 that $\mathrm{NO}_{x}$ emission levels rise more rapidly when the mixture has a higher proportion of $\mathrm{H}_{2}$. As expected, this is due to $\mathrm{H}_{2}$ exhibiting a shorter ignition 
delay and combusting closer to TDC, resulting in higher gas temperatures (Figure 6), and hence increased thermal $\mathrm{NO}_{x}$ formation rates. Preliminary calculations of adiabatic flame temperatures resulting from the two gas mixtures indicate that flame temperatures from the $20 \mathrm{CH}_{4}: 80 \mathrm{H}_{2}$ mixture are about $200-250 \mathrm{~K}$ higher, as compared to the $80 \mathrm{CH}_{4}: 20 \mathrm{H}_{2}$ mixture.

Now considering $\mathrm{NO}_{\mathrm{x}}$ emissions for a pilot diesel fuel IMEP of 1.5 bar (Figure 9), similar trends to those described in the paragraph above can be observed with increasing engine loads and with different $\mathrm{CH}_{4}-\mathrm{H}_{2}$ mixtures. However, the $\mathrm{NO}_{x}$ emissions start increasing rapidly above 3 bar IMEP, as compared to the 4 bar IMEP threshold observed with a pilot diesel fuel IMEP of 0 bar. This may be attributed to the higher amount of pilot diesel fuel being injected into the combustion chamber to achieve a 1.5 bar IMEP. As mentioned before, the larger amount of diesel fuel being injected into the cylinder results in a higher in-cylinder gas temperatures, sufficient for significant $\mathrm{NO}_{\mathrm{x}}$ formation [40]. Therefore, the temperatures resulting from the combined $\mathrm{CH}_{4}-\mathrm{H}_{2}$-diesel fuel combustion are likely to reach the threshold for accelerated thermal $\mathrm{NO}_{\mathrm{x}}$ formation at a lower load of 3 bar IMEP.

Figure 9 also shows the $\mathrm{NO}_{x}$ exhaust emissions when the engine load is increased without any $\mathrm{CH}_{4}$ or $\mathrm{H}_{2}$ addition, that is, by merely increasing the amount of diesel fuel injected. It can be observed that although the $\mathrm{NO}_{\mathrm{x}}$ levels do increase with increasing engine load when only diesel fuel is used, the rise in $\mathrm{NO}_{x}$ levels is not as rapid as observed in the case of $\mathrm{CH}_{4}-\mathrm{H}_{2}$ mixture combustion. As explained above, diesel combustion occurs at close-to-stoichiometric conditions, whereas the aspirated $\mathrm{CH}_{4} / \mathrm{H}_{2}$-air mixtures are considerably below stoichiometric levels. Hence, as the supply of $\mathrm{CH}_{4}-\mathrm{H}_{2}$ mixture to the engine is increased (that is, the in-cylinder mixture proceeds towards stoichiometric conditions), it is likely that the increase in temperatures is significantly greater than that obtained just with increasing diesel fuel, resulting in the rapid increase in $\mathrm{NO}_{\mathrm{x}}$ emissions. 


\subsection{Particulate exhaust emissions}

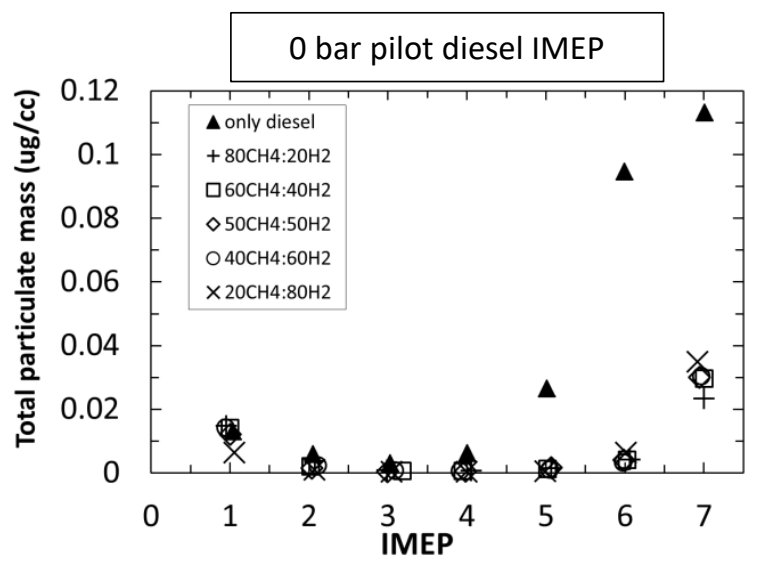

(a)

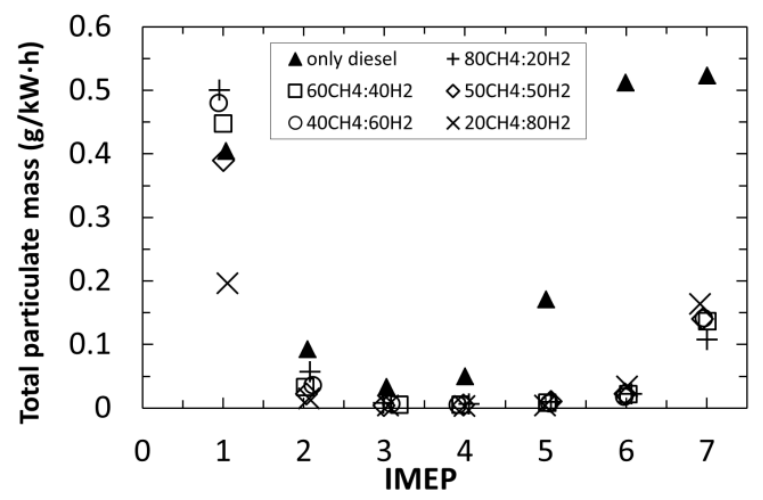

(c)

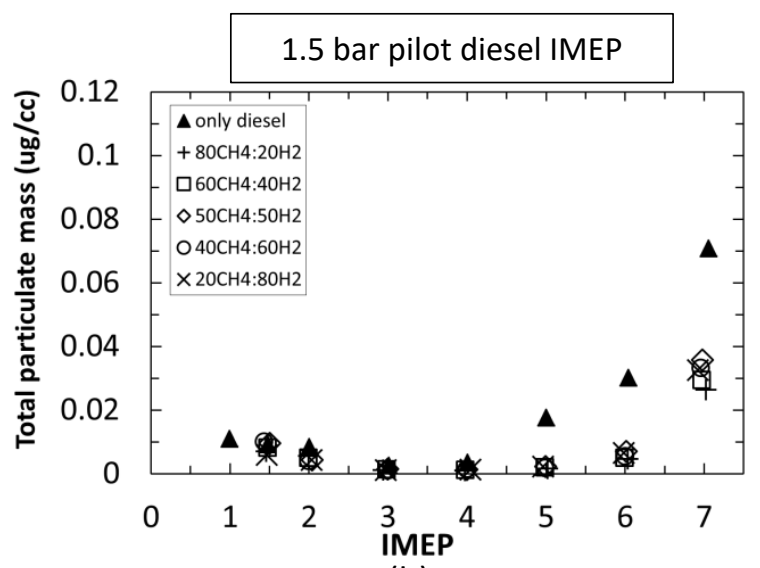

(b)

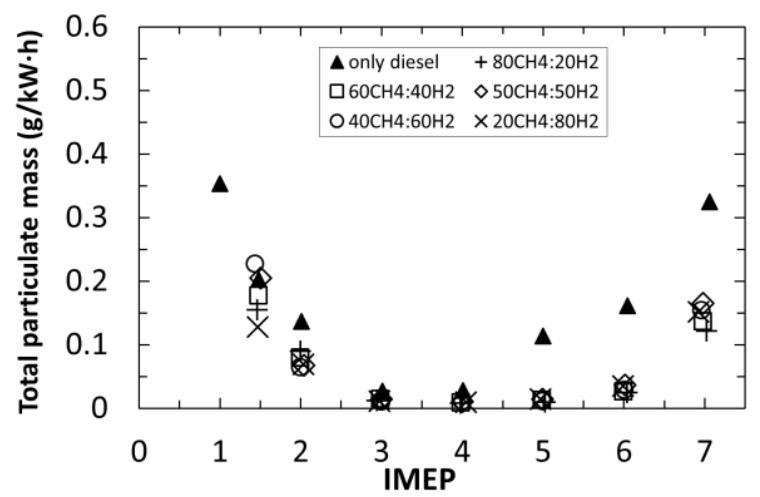

(d)

Figure 10: Exhaust emissions of total particulate mass ( $\mu \mathrm{g} / \mathrm{cc}$ and $\mathrm{g} / \mathrm{kW} . \mathrm{h}$ ) for the two pilot diesel fuel IMEPs, at various engine loads and $\mathrm{CH}_{4}-\mathrm{H}_{2}$ mixture proportions.

Figure 10 shows the exhaust emissions of total particulate mass (PM) for the two pilot diesel fuel IMEPs of 0 bar and 1.5 bar, at various engine loads and $\mathrm{CH}_{4}-\mathrm{H}_{2}$ mixture proportions, in both $\mu \mathrm{g} / \mathrm{cc}$ and $\mathrm{g} / \mathrm{kW} \cdot \mathrm{h}$. It can be observed that for both the pilot diesel IMEPs and for all $\mathrm{CH}_{4}-\mathrm{H}_{2}$ mixture proportions, the level of PM emissions does not increase with increasing engine load (achieved by increasing the $\mathrm{CH}_{4}-\mathrm{H}_{2}$ mixture supply) up to 6 bar IMEP, beyond which a rapid increase in PM emissions is seen. The introduction of $\mathrm{CH}_{4}$ and $\mathrm{H}_{2}$ in the cylinder is likely to have two competing effects on PM formation, increased oxidation rates and increased pyrolysis rates. It is possible that for engine loads above 6 bar IMEP, the displacement of intake air by $\mathrm{CH}_{4}$ and $\mathrm{H}_{2}$ leads to sufficient reduction in $\mathrm{O}_{2}$ availability for hydrocarbon combustion, resulting in increased pyrolysis rates. Comparing the particulate mass in units of $\mu \mathrm{g} / \mathrm{cc}$ and $\mathrm{g} / \mathrm{kW} \cdot \mathrm{h}$, while the absolute values of particulate mass are different in some cases, the observed trends in the change in particulate mass with load are consistent between the two different units. 
Figure 10 also shows the total particulate mass (PM) emissions when the engine load is increased without any $\mathrm{CH}_{4}$ or $\mathrm{H}_{2}$ addition, that is, by merely increasing the amount of diesel fuel injected. It is interesting to note that at engine loads of 5, 6 and 7 bar IMEP, the PM emissions from diesel only engine operation are significantly higher as compared to diesel fuel- $\mathrm{CH}_{4}-\mathrm{H}_{2}$ combustion. This is, in part, due to replacing the diesel fuel with 'zero' carbon $\mathrm{H}_{2}$, but also shows that $\mathrm{CH}_{4}$ tends very little towards the formation of particulates as compared to diesel fuel. This could be due to the aspirated $\mathrm{CH}_{4}$ being well mixed with the intake air, while the injected diesel fuel spray contains fuel-rich and oxygen deficient core regions where the majority of the particulates originate from [40].

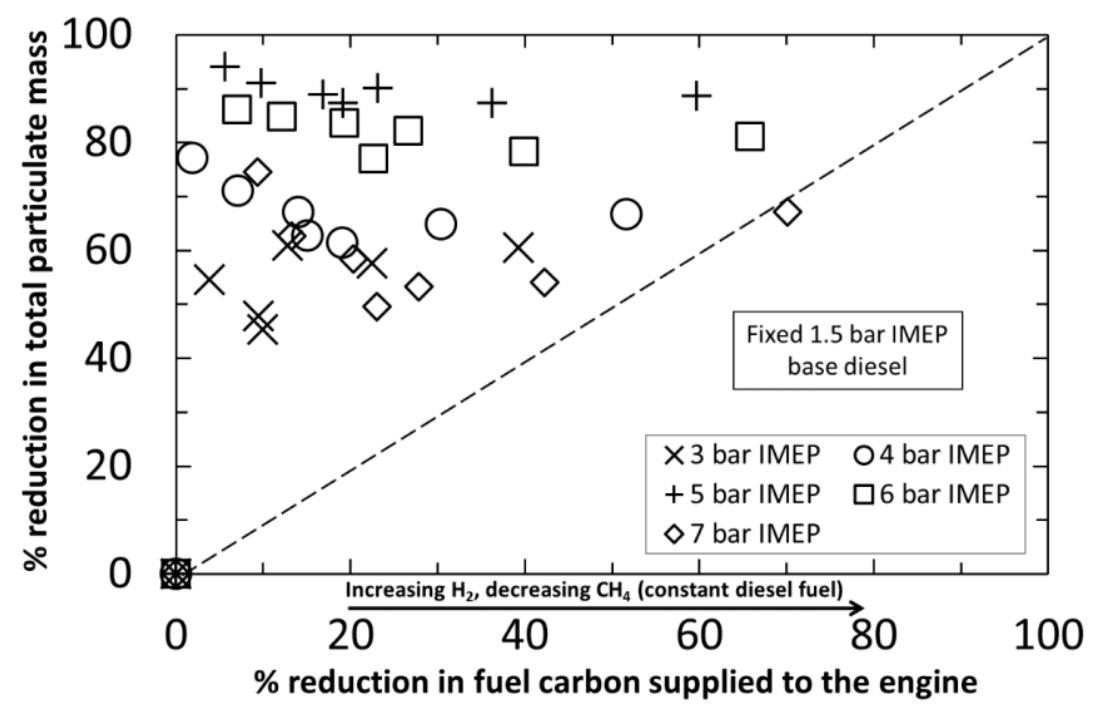

Figure 11: Percentage reductions in total particulate mass against carbon content of the combustible mixture at constant engine loads and for a fixed pilot diesel fuel IMEP of $\mathbf{1 . 5}$ bar.

Figure 11 shows the percentage reduction in the total particulate mass plotted against the percentage reduction in fuel carbon supplied to the engine, at constant engine loads and for a fixed pilot diesel fuel IMEP of 1.5 bar. The reduction in fuel carbon was achieved by lowering the proportion of $\mathrm{CH}_{4}$ and increasing the proportion of $\mathrm{H}_{2}$ in the aspirated $\mathrm{CH}_{4}-\mathrm{H}_{2}$ mixture in order to maintain a constant engine load. The percentage reductions in both particulates and fuel carbon were calculated against the values obtained with the engine operating on only diesel fuel (no $\mathrm{CH}_{4}$ or $\mathrm{H}_{2}$ addition). The 1:1 dashed diagonal line in Figure 11 represents equivalent reductions in both PM emissions and fuel carbon supplied to the engine.

For all engine loads shown in Figure 11, the reductions in PM emissions lie in the top half of the graph (above the 1:1 dashed line), implying a beneficial effect of replacing diesel fuel with $\mathrm{CH}_{4}-\mathrm{H}_{2}$ mixture on PM reduction beyond simple fuel carbon displacement. For example at a constant engine load 4 bar IMEP, a $20 \%$ reduction in fuel carbon causes up to $60 \%$ reduction in particulate matter. As previously discussed, this is due to premixed $\mathrm{CH}_{4}$ having a lower tendency of forming particulates as 
compared to the injected diesel fuel (which will always have regions of rich stoichiometry). Now comparing the reduction in PM emissions between different engine loads, an increase in the percentage reduction in PM emissions can be observed from Figure 11 as the engine load increases from 3 bar to 5 bar IMEP. However, as the engine load is further increased to 7 bar IMEP, the percentage reduction in PM emissions decreases. It should be remembered here that all the tests were conducted at a fixed diesel fuel flow into the engine (equivalent to pilot diesel fuel IMEP of 1.5 bar), and any increase in engine load was achieved by increasing the amount of $\mathrm{CH}_{4}-\mathrm{H}_{2}$ mixture being aspirated into the engine (hence displacing intake air). It is likely that the increase in the supply of $\mathrm{CH}_{4}-\mathrm{H}_{2}$ mixture to the engine (to increase the engine load up to 5 bar IMEP) resulted in higher incylinder gas temperatures, leading to higher carbon oxidation rates and lower PM emissions. However, as the amount of aspirated $\mathrm{CH}_{4}-\mathrm{H}_{2}$ mixture is further increased (to increase the engine load above 5 bar IMEP), the effect of $\mathrm{O}_{2}$ unavailability for PM oxidation becomes more important than the increase in in-cylinder temperatures arising from higher $\mathrm{CH}_{4} / \mathrm{H}_{2}$-air equivalence ratios.

Figure 11 allows another interesting observation to be made in the case of the intermediate engine load of 5 bar IMEP. Firstly, the figure shows clearly that when the engine is running mainly on $\mathrm{CH}_{4}$ (with only a small quantity of pilot diesel fuel), there is a large reduction in particulates (of up to $90 \%$ ) in comparison to when the engine is run at 5 bar IMEP using only diesel fuel. This could be ascribed to the lower carbon/hydrogen ratio of $\mathrm{CH}_{4}$ (compared with that for diesel fuel); and also, due to the fact that $\mathrm{CH}_{4}$ is premixed and at a lean stoichiometric ratio. Figure 11 further shows that at 5 bar IMEP when the $\mathrm{CH}_{4}$ is progressively substituted by $\mathrm{H}_{2}$ there is no additional benefit in reduction of particulates. One explanation for this is that $\mathrm{CH}_{4}$ hardly make any particulates, and its substitution with $\mathrm{H}_{2}$ could not be expected to provide any benefit in terms of further reduction in particulates. Furthermore, it could be concluded that the $\mathrm{H}_{2}$ is not providing any benefit in helping to reduce the particulates formed by the pilot diesel fuel. 


\subsection{In-cylinder gas sample composition}
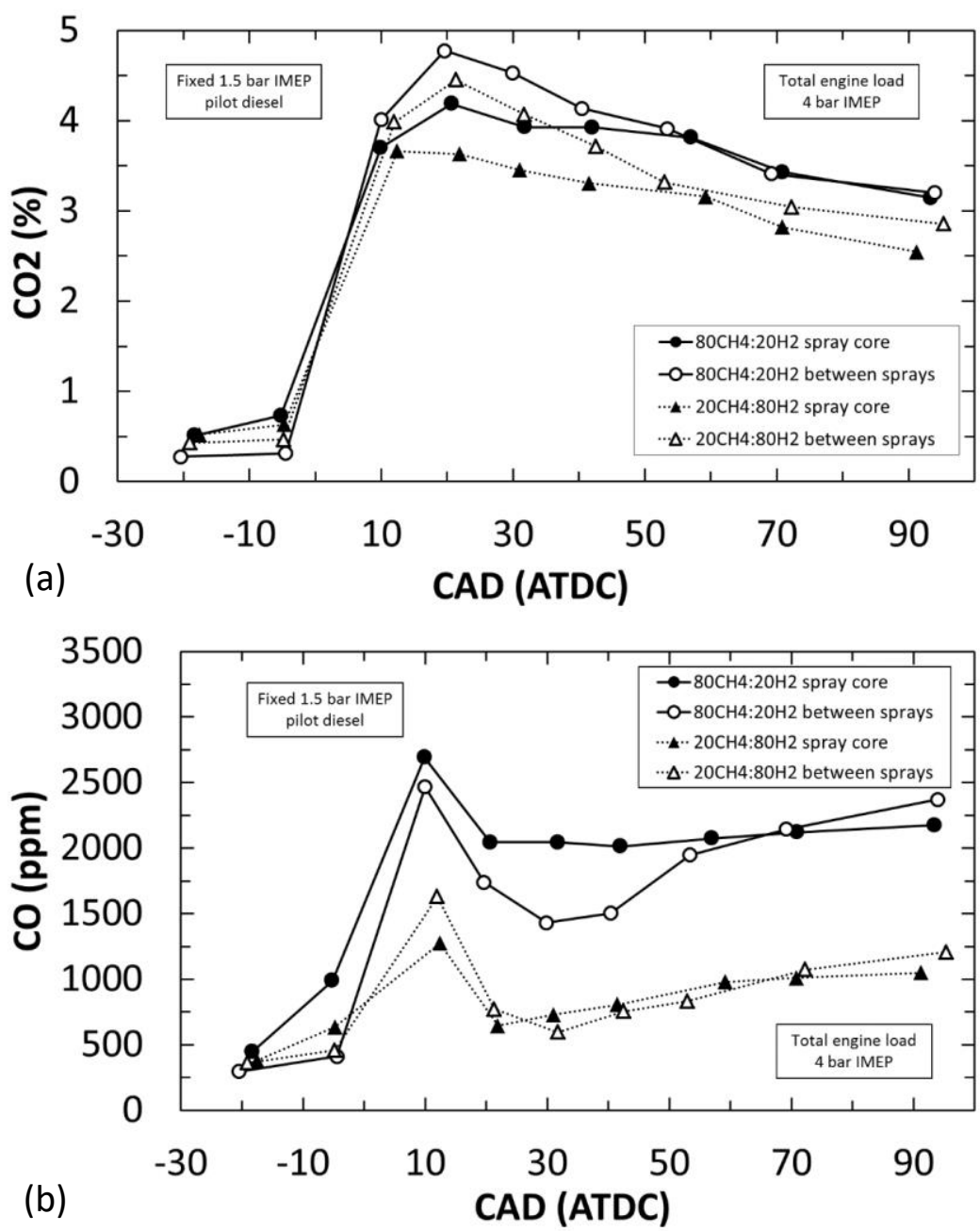

Figure 12: In-cylinder concentrations of (a) carbon dioxide $\left(\mathrm{CO}_{2}\right)$ and (b) carbon monoxide $(\mathrm{CO})$ collected between -20 and 100 CAD ATDC with two sampling arrangements, and an overall engine load of 4 bar IMEP.

Figure 12 (a) shows the $\mathrm{CO}_{2}$ concentration in gas samples extracted from the engine cylinder at various CAD degrees ranging between -20 CAD and 100 CAD ATDC, with the two sampling arrangements (Figure 5). The amount of diesel fuel being injected into the cylinder was kept fixed (equivalent to 1.5 bar pilot diesel IMEP), and the overall engine load of 4 bar IMEP achieved by aspirating the necessary amount of $\mathrm{CH}_{4}-\mathrm{H}_{2}$ mixture with the intake air. At -20 CAD ATDC, the $\mathrm{CO}_{2}$ concentration is quite similar at the four test conditions; this is expected, since at this time in the engine cycle no diesel fuel has been injected in to the cylinder, nor has combustion taken place. Furthermore, the $\mathrm{CO}_{2}$ concentration at -20 CAD ATDC reflects the composition of the residual combustion gases trapped in the cylinder from the preceding engine cycle. After diesel fuel injection (at -10 CAD ATDC) and subsequent ignition (at about 0 CAD ATDC) takes place, the in-cylinder $\mathrm{CO}_{2}$ concentration is observed to rise sharply, indicating rapid fuel combustion during the premixed burning phase. First, comparing the in-cylinder $\mathrm{CO}_{2}$ concentration (post ignition, at about $20 \mathrm{CAD}$ 
ATDC), between the two different $\mathrm{CH}_{4}-\mathrm{H}_{2}$ mixture proportions used, it can be seen from Figure 12 (a) that mixtures with a higher proportion of $\mathrm{CH}_{4}$ (than $\mathrm{H}_{2}$ ) yield a higher amount of $\mathrm{CO}_{2}$. Now, comparing the post ignition in-cylinder $\mathrm{CO}_{2}$ concentration between the two sampling arrangements, it can be observed that, for both $\mathrm{CH}_{4}-\mathrm{H}_{2}$ mixtures, the $\mathrm{CO}_{2}$ concentration is higher between the sprays than in the spray core. Therefore, considering the differences in the $\mathrm{CO}_{2}$ concentrations, the region in between two diesel fuel sprays could be expected to have a higher concentration of $\mathrm{CH}_{4}$-air mixture which burns to form $\mathrm{CO}_{2}$. In contrast, the lower $\mathrm{CO}_{2}$ concentration within the diesel spray core region could be attributed to the lack of air entrainment in the fuel spray, especially during the initial stages of combustion. Furthermore, the difference in the in-cylinder $\mathrm{CO}_{2}$ concentrations could just be due to the relative amounts of carbon in the injected diesel fuel (to achieve a pilot diesel IMEP of 1.5 bar) and in the aspirated $\mathrm{CH}_{4}$. Beyond 20 CAD ATDC, the $\mathrm{CO}_{2}$ concentration at the four test conditions slowly decreased as the expansion stroke progressed. This is assumed to be the result of the burned gas products become further diluted with the unreacted intake air that moves from within the piston bowl to the region above the piston during the expansion stroke.

Figure 12 (b) shows the CO concentration in gas samples extracted from the engine cylinder at various CAD degrees ranging between -20 CAD and 100 CAD ATDC, for the two $\mathrm{CH}_{4}-\mathrm{H}_{2}$ mixture proportions and with the two sampling arrangements (Figure 5). The in-cylinder CO concentration increases significantly following ignition at about 0 CAD ATDC, as the burning process initiates and carbon oxidation begins. Peak CO levels are reached at about 10 CAD ATDC and, as expected, the CO concentration is higher when the aspirated $\mathrm{CH}_{4}-\mathrm{H}_{2}$ mixture contains a higher proportion of $\mathrm{CH}_{4}$. The CO concentration is then observed to decrease sharply between 10 and 20 CAD ATDC, which is consistent with the increase in the in-cylinder $\mathrm{CO}_{2}$ concentration between 10 and 20 CAD ATDC (Figure 12 (a)), as the $\mathrm{CO}$ oxidises to form $\mathrm{CO}_{2}$. Comparing the peak $\mathrm{CO}$ levels (at 10 CAD ATDC) between the two sampling arrangements, it can be observed that the $\mathrm{CO}$ concentration is higher within the spray core when the aspirated $\mathrm{CH}_{4}: \mathrm{H}_{2}$ mixture has a higher proportion of $\mathrm{CH}_{4}$. In contrast, when the $\mathrm{CH}_{4}: \mathrm{H}_{2}$ mixture being supplied to the engine has a higher proportion of $\mathrm{H}_{2}$, the $\mathrm{CO}$ concentration is lower within in the spray core. 

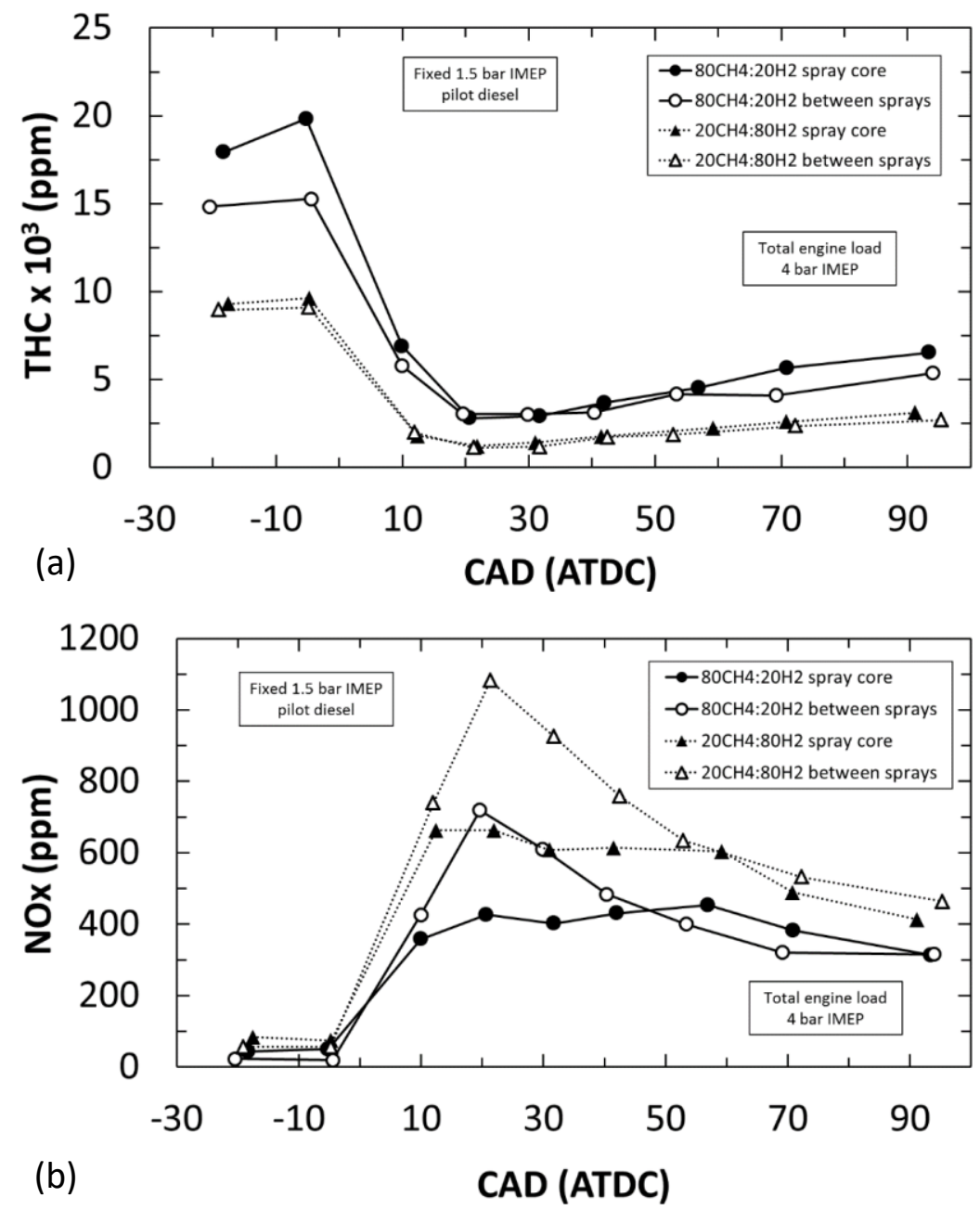

Figure 13: In-cylinder concentrations of (a) Unburned hydrocarbon (THC) and (b) $\mathrm{NO}_{x}$ collected between -20 and 100 CAD ATDC with two sampling arrangements, and an overall engine load of 4 bar IMEP.

Figure 13 (a) shows the unburned THC concentration in gas samples extracted from the engine cylinder at various CAD degrees ranging between -20 CAD and 100 CAD ATDC, for the two $\mathrm{CH}_{4}-\mathrm{H}_{2}$ mixture proportions and with the two sampling arrangements (Figure 5). At -20 CAD ATDC, prior to diesel fuel injection, the in-cylinder THC concentration is higher for the $80 \mathrm{CH}_{4}: 20 \mathrm{H}_{2}$ mixture, as compared to the $20 \mathrm{CH}_{4}: 80 \mathrm{H}_{2}$ mixture, due to higher proportion of $\mathrm{CH}_{4}$ in the aspirated mixture. Following ignition at about 0 CAD ATDC, a sharp decrease in THC concentration is observed (up to 20 CAD ATDC) as the diesel fuel and $\mathrm{CH}_{4}$ are consumed. However, a higher concentration of unburned THC is maintained for mixture of $80 \mathrm{CH}_{4}: 20 \mathrm{H}_{2}$ beyond 20 CAD ATDC.

Figure 13 (b) shows the $\mathrm{NO}_{x}$ concentration in gas samples extracted from the engine cylinder at various CAD degrees ranging between -20 CAD and 100 CAD ATDC, for the two $\mathrm{CH}_{4}-\mathrm{H}_{2}$ mixture proportions and with the two sampling arrangements (Figure 5). Following ignition at about 0 CAD ATDC, $\mathrm{NO}_{x}$ concentrations are observed to increase and reach peak values at about 20 CAD ATDC. Comparing the in-cylinder $\mathrm{NO}_{x}$ concentration between the two $\mathrm{CH}_{4}-\mathrm{H}_{2}$ mixtures with both the 
sampling arrangements, it can be observed that $\mathrm{NO}_{x}$ levels are higher when $\mathrm{H}_{2}$ is present in a greater proportion in the aspirated $\mathrm{CH}_{4}-\mathrm{H}_{2}$ mixture. As previously discussed, $\mathrm{H}_{2}$ exhibits a shorter ignition delay, combusting closer to TDC and resulting in higher gas temperatures reached inside the cylinder. Since $\mathrm{NO}_{x}$ formation is primarily a thermal process $[39,41,42]$, higher in-cylinder gas temperatures can be expected to result in higher $\mathrm{NO}_{x}$ formation rates.

Now, comparing the $\mathrm{NO}_{x}$ concentration between the two sampling arrangements (within the diesel fuel spray core and between two sprays) at 20 CAD ATDC, it can be observed from Figure 13 (b), for both $\mathrm{CH}_{4}-\mathrm{H}_{2}$ mixture proportions, that $\mathrm{NO}_{x}$ levels are higher in the region between the two sprays as compared to within the spray core. These results are consistent with the in-cylinder $\mathrm{NO}_{\mathrm{x}}$ concentration results obtained from $\mathrm{H}_{2}$-diesel fuel co-combustion experiments conducted previously by the author [31]. During the initial stages of combustion, the entrainment of air into the diesel fuel spray cone due to the turbulent swirling motion inside the cylinder results in the mixing of the fuel vapour at the periphery of the spray with the intake charge, especially in the region between the individual sprays [24]. As mentioned previously, it is expected that autoignition first occurs at these near stoichiometric diesel fuel vapour-air pockets around the fuel sprays [40] and results in the rapid burning of both premixed diesel vapour and the $\mathrm{CH}_{4} / \mathrm{H}_{2}$-air mixtures (which occur in a higher concentration between fuel sprays as compared to within the spray core during these initial stages of combustion) around the diesel fuel ignition sites. It is suggested that the temperature rise from the combined diesel fuel- $\mathrm{CH}_{4}-\mathrm{H}_{2}$ combustion exceeds the threshold for accelerated thermal $\mathrm{NO}_{x}$ formation, resulting in high $\mathrm{NO}_{\mathrm{x}}$ levels in the region between two individual sprays. On the other hand, the lower $\mathrm{NO}_{\mathrm{x}}$ concentration in the spray core (at about 20 CAD ATDC) may possibly be attributable to the relatively low concentration of entrained air into the diesel fuel rich spray core during the initial stages of combustion (prior to complete spray break up), resulting in lower postcombustion temperatures and hence, reduced $\mathrm{NO}_{x}$ formation. Additionally, some of the energy released in this fuel rich region may be expected to have been absorbed for fuel pyrolysis [35], possibly leading to lower gas temperatures and $\mathrm{NO}_{x}$ formation rates.

An interesting phenomenon can be observed in Figures 12 and 13, whereby beyond 30 CAD ATDC the in-cylinder $\mathrm{CO}_{2}$ and $\mathrm{NO}_{\mathrm{x}}$ levels decrease while, for the same period, the in-cylinder $\mathrm{CO}$ and THC levels increase. One would expect that the decrease in $\mathrm{CO}_{2}$ and $\mathrm{NO}_{x}$ levels due to mixing with unreacted air would also be reflected in reductions in CO and THC. A potential explanation for this apparent contradiction might relate to a reduction in combustion temperature (hence in fuel oxidation rates), due to mixing of the combustion zone with unreacted air plus the expansion of the engine cylinder volume, which could have caused the concentration of partially oxidized products 
( $\mathrm{CO}$ and $\mathrm{THC}$ ) to rise despite their concentrations also being diluted at the same time by mixing with unreacted air.

\section{Conclusions}

The following points summarise the main results from the work carried out this paper:

1. The use of $\mathrm{CH}_{4}-\mathrm{H}_{2}$ mixtures in $\mathrm{Cl}$ engines can potentially counter the drawbacks associated with separate $\mathrm{CH}_{4}$ and $\mathrm{H}_{2}$ combustion, such as the slow flame propagation velocities of $\mathrm{CH}_{4}$, or phenomenon such as backfire and knock encountered when combusting $\mathrm{H}_{2}$.

2. For same $\mathrm{CH}_{4}-\mathrm{H}_{2}$ mixture proportion and engine load, shorter ignition delay periods and higher peak heat release rates closer to the engine TDC position were observed with a higher amount of pilot diesel fuel flow rate. Increasing the proportion of $\mathrm{H}_{2}$ in the $\mathrm{CH}_{4}-\mathrm{H}_{2}$ mixture also reduced the ignition delay period and increased peak heat release rates, but only at high engine loads above 6 bar IMEP.

3. At all engine loads, exhaust $\mathrm{CO}_{2}$ emissions were considerably lower when operating the engine on $\mathrm{CH}_{4}-\mathrm{H}_{2}$ mixtures relative to diesel fuel only engine operation, attributable to the lower carbon to hydrogen ratio of $\mathrm{CH}_{4}$ compared to diesel fuel.

4. For all $\mathrm{CH}_{4}-\mathrm{H}_{2}$ mixtures tested, the exhaust $\mathrm{CO}$ and unburned THC emissions were observed to be considerably high (compared to diesel fuel only operation) below 4 bar IMEP due to low temperature quenching effects. Above 4 bar IMEP, the increased in-cylinder temperatures enabled improved $\mathrm{CO}$ and hydrocarbon oxidation rates and hence, decreased $\mathrm{CO}$ and unburned THC emissions.

5. For both fixed pilot diesel fuel IMEPs of 0 bar and 1.5 bar, $\mathrm{NO}_{x}$ emissions were observed to increase rapidly with increasing engine load, but only when the in-cylinder temperatures due to combined diesel fuel and $\mathrm{CH}_{4}-\mathrm{H}_{2}$ mixture combustion exceeded the temperature threshold for $\mathrm{NO}_{x}$ formation.

6. Significant reductions in PM emissions were observed when diesel fuel was replaced with $\mathrm{CH}_{4}-\mathrm{H}_{2}$ mixtures. For a fixed pilot diesel IMEP, the magnitude of PM reduction increased when the engine load was increased up to 5 bar IMEP (by increasing the supply of $\mathrm{CH}_{4}-\mathrm{H}_{2}$ mixture). Increasing the engine load above 5 bar IMEP, significantly lowered the magnitude of PM reduction, attributable to excessive displacement of intake $\mathrm{O}_{2}$ by the $\mathrm{CH}_{4}-\mathrm{H}_{2}$ mixture.

7. In-cylinder gas sampling experiments were conducted to observe the spatial and temporal variations in stable species formed within the combustion chamber. During the early stages of combustion, an appreciable contrast was observed in the concentration of pollutant species between the two sampling arrangements considered (between the sprays and within the spray core). While in the later stages of engine cycle, the distinction in species concentration (between the two 
arrangements) was considerably less, attributable to the effects of turbulent mixing as the expansion stroke progressed.

8. Comparing the $\mathrm{NO}_{x}$ levels obtained with the two sampling arrangements, the $\mathrm{NO}_{\mathrm{x}}$ concentration was higher in the region between the sprays as compared to within the spray core. This was attributed to higher temperatures reached post ignition, in the region between two individual fuel sprays due to presence of a higher concentration of $\mathrm{CH}_{4}-\mathrm{H}_{2}$ mixture in that region (as compared to within the spray core).

9. The observed trends in exhaust emissions with different $\mathrm{CH}_{4}: \mathrm{H}_{2}$ mixtures were observed to correspond with the trends in in-cylinder species concentrations. As an example, both the exhaust gas and in-cylinder $\mathrm{NO}_{x}$ levels were observed to increase with increasing proportion of $\mathrm{H}_{2}$ in the aspirated $\mathrm{CH}_{4}-\mathrm{H}_{2}$ mixture.

\section{Nomenclature}

\begin{tabular}{|c|c|}
\hline ATDC & after-top-dead-centre \\
\hline BTDC & before-top-dead-centre \\
\hline CAD & crank angle degree \\
\hline $\mathrm{CH}_{4}$ & methane \\
\hline $\mathrm{Cl}$ & compression ignition \\
\hline $\mathrm{CO}$ & carbon monoxide \\
\hline $\mathrm{CO}_{2}$ & carbon dioxide \\
\hline $\mathrm{H}_{2}$ & hydrogen \\
\hline IMEP & indicated mean effective pressures \\
\hline NO & nitric oxide \\
\hline $\mathrm{NO}_{\mathrm{x}}$ & nitrogen oxides \\
\hline $\mathrm{O}_{2}$ & oxygen \\
\hline $\mathrm{OH}$ & hydroxyl \\
\hline PM & particulate mass \\
\hline ppm & parts per million \\
\hline $\mathrm{rpm}$ & revolutions per minute \\
\hline SOC & start of combustion \\
\hline SOI & start of injection \\
\hline TDC & top -dead -centre \\
\hline THC & total hydrocarbons \\
\hline$\phi_{\mathrm{CH} 4}$ & methane-air equivalence ratio \\
\hline$\phi_{\mathrm{H} 2}$ & hydrogen-air equivalence ratio \\
\hline
\end{tabular}

\section{References}

[1] Karim G. Hydrogen as a spark ignition engine fuel. International Journal of Hydrogen Energy 2003;56:256-63.

[2] Klell M, Eichlseder $H$, Sartory $M$. Mixtures of hydrogen and methane in the internal combustion engine - Synergies, potential and regulations. International Journal of Hydrogen 
Energy 2012;37:11531-40. doi:10.1016/j.ijhydene.2012.03.067.

[3] Diéguez PM, Urroz JC, Marcelino-Sádaba S, Pérez-Ezcurdia A, Benito-Amurrio M, Sáinz D, et al. Experimental study of the performance and emission characteristics of an adapted commercial four-cylinder spark ignition engine running on hydrogen-methane mixtures. Applied Energy 2014;113:1068-76. doi:10.1016/j.apenergy.2013.08.063.

[4] Akansu S, Kahraman N, Ceper B. Experimental study on a spark ignition engine fuelled by methane-hydrogen mixtures. International Journal of Hydrogen Energy 2007;32:4279-84. doi:10.1016/j.jihydene.2007.05.034.

[5] Nagalingam B, Duebel F, Schmillen K. Performance study using natural gas, hydrogensupplemented natural gas and hydrogen in AVL research engine. International Journal of Hydrogen Energy 1983;8:715-20. doi:10.1016/0360-3199(83)90181-7.

[6] Demuynck J, Raes N, Zuliani M, De Paepe M, Sierens R, Verhelst S. Local heat flux measurements in a hydrogen and methane spark ignition engine with a thermopile sensor. International Journal of Hydrogen Energy 2009;34:9857-68. doi:10.1016/j.jjhydene.2009.10.035.

[7] Verhelst S, Demuynck J, Sierens R, Huyskens P. Impact of variable valve timing on power, emissions and backfire of a bi-fuel hydrogen/gasoline engine. International Journal of Hydrogen Energy 2010;35:4399-408. doi:10.1016/j.ijhydene.2010.02.022.

[8] Swain MR, Yusuf MJ, Dülger Z, Swain MN. The Effects of Hydrogen Addition on Natural Gas Engine Operation. SAE Paper 1993:932775. doi:10.4271/932775.

[9] Wallace J, Cattelan A. Hythane and CNG fueled engine exhaust emission comparison. 10th World hydrogen Energy Conference, Cocoa Beach, USA: 1994, p. 1761-70.

[10] Raman V, Hansel J, Fulton J, Brudery D. Hythane-an ultraclean transport fuel. 10th World hydrogen Energy Conference, Cocoa Beach, USA: 1994, p. 1797-806.

[11] Hoekstra R. Experimental study of a clean burning vehicle fuel. International Journal of Hydrogen Energy 1995;20:737-45. doi:10.1016/0360-3199(95)00008-2.

[12] Liu Z, Karim G. Knock characteristics of dual-fuel engines fuelled with hydrogen fuel. International Journal of Hydrogen Energy 1995;20:919-24. doi:10.1016/0360-3199(95)000237.

[13] Karim G, Wierzba I, Al-Alousi Y. Methane-hydrogen mixtures as fuels. International Journal of Hydrogen Energy 1996;21:625-31. doi:10.1016/0360-3199(95)00134-4.

[14] Larsen JF, Wallace JS. Comparison of Emissions and Efficiency of a Turbocharged Lean-Burn Natural Gas and Hythane-Fueled Engine. Journal of Engineering for Gas Turbines and Power 1997;119:218. doi:10.1115/1.2815553. 
[15] Van Blarigan P, Keller JO. A hydrogen fuelled internal combustion engine designed for single speed/power operation. International Journal of Hydrogen Energy 1998;23:603-9. doi:10.1016/S0360-3199(97)00100-6.

[16] Shrestha S. Hydrogen as an additive to methane for spark ignition engine applications. International Journal of Hydrogen Energy 1999;24:577-86. doi:10.1016/S03603199(98)00103-7.

[17] Das L. A comparative evaluation of the performance characteristics of a spark ignition engine using hydrogen and compressed natural gas as alternative fuels. International Journal of Hydrogen Energy 2000;25:783-93. doi:10.1016/\$0360-3199(99)00103-2.

[18] Bauer C. Effect of hydrogen addition on the performance of methane-fueled vehicles. Part II: driving cycle simulations. International Journal of Hydrogen Energy 2001;26:71-90. doi:10.1016/S0360-3199(00)00061-6.

[19] Bauer C. Effect of hydrogen addition on the performance of methane-fueled vehicles. Part I: effect on S.I. engine performance. International Journal of Hydrogen Energy 2001;26:55-70. doi:10.1016/S0360-3199(00)00067-7.

[20] Akansu S. Internal combustion engines fueled by natural gas-hydrogen mixtures. International Journal of Hydrogen Energy 2004;29:1527-39. doi:10.1016/j.ijhydene.2004.01.018.

[21] Kahraman N, Ceper B, Akansu S, Aydin K. Investigation of combustion characteristics and emissions in a spark-ignition engine fuelled with natural gas-hydrogen blends. International Journal of Hydrogen Energy 2009;34:1026-34. doi:10.1016/j.ijhydene.2008.10.075.

[22] Thurnheer T, Soltic P, Dimopoulos Eggenschwiler P. S.I. engine fuelled with gasoline, methane and methane/hydrogen blends: Heat release and loss analysis. International Journal of Hydrogen Energy 2009;34:2494-503. doi:10.1016/j.jjhydene.2008.12.048.

[23] McTaggart-Cowan GP, Rogak SN, Munshi SR, Hill PG, Bushe WK. Combustion in a heavy-duty direct-injection engine using hydrogen-methane blend fuels. International Journal of Engine Research 2009;10:1-13. doi:10.1243/14680874JER02008.

[24] Gatts T, Li H, Liew C, Liu S, Spencer T, Wayne S, et al. An experimental investigation of H2 emissions of a 2004 heavy-duty diesel engine supplemented with H2. International Journal of Hydrogen Energy 2010;35:11349-56. doi:10.1016/j.ijhydene.2010.06.056.

[25] Imran S, Emberson DR, Ihracska B, Wen DS, Crookes RJ, Korakianitis T. Effect of pilot fuel quantity and type on performance and emissions of natural gas and hydrogen based combustion in a compression ignition engine. International Journal of Hydrogen Energy 2014;39:5163-75. doi:10.1016/j.ijhydene.2013.12.108. 
[26] Zhou JH, Cheung CS, Leung CW. Combustion, performance and emissions of a diesel engine with $\mathrm{H} 2, \mathrm{CH} 4$ and $\mathrm{H} 2-\mathrm{CH} 4$ addition. International Journal of Hydrogen Energy 2014;39:461121. doi:10.1016/j.ijhydene.2013.12.194.

[27] Saravanan N, Nagarajan G. Combustion analysis on a DI diesel engine with hydrogen in dual fuel mode. Fuel 2008;87:3591-9. doi:10.1016/j.fuel.2008.07.011.

[28] Masood $M$, Ishrat $M$, Reddy A. Computational combustion and emission analysis of hydrogen-diesel blends with experimental verification. International Journal of Hydrogen Energy 2007;32:2539-47. doi:10.1016/j.ijhydene.2006.11.008.

[29] Christodoulou F, Megaritis A. Experimental investigation of the effects of separate hydrogen and nitrogen addition on the emissions and combustion of a diesel engine. International Journal of Hydrogen Energy 2013;38:10126-40. doi:10.1016/j.ijhydene.2013.05.173.

[30] Wang J, Huang Z, Tang C, Miao H, Wang X. Numerical study of the effect of hydrogen addition on methane-air mixtures combustion. International Journal of Hydrogen Energy 2009;34:1084-96. doi:10.1016/j.ijhydene.2008.11.010.

[31] Talibi M, Hellier P, Balachandran R, Ladommatos N. Effect of hydrogen-diesel fuel cocombustion on exhaust emissions with verification using an in-cylinder gas sampling technique. International Journal of Hydrogen Energy 2014;39:15088-102. doi:10.1016/j.ijhydene.2014.07.039.

[32] Talibi M, Hellier P, Balachandran R, Ladommatos N. Development of a Fast-Acting, TimeResolved Gas Sampling System for Combustion and Fuels Analysis. SAE International Journal of Engines 2016;9:2016-01 - 0791. doi:10.4271/2016-01-0791.

[33] Saravanan N, Nagarajan G. An experimental investigation of hydrogen-enriched air induction in a diesel engine system. International Journal of Hydrogen Energy 2008;33:1769-75. doi:10.1016/j.jjhydene.2007.12.065.

[34] Chong CT, Hochgreb S. Measurements of laminar flame speeds of liquid fuels: Jet-A1, diesel, palm methyl esters and blends using particle imaging velocimetry (PIV). Proceedings of the Combustion Institute 2011;33:979-86. doi:10.1016/j.proci.2010.05.106.

[35] Heywood JB. Internal Combustion Engine Fundamentals. 1st ed. New York: McGraw-Hill; 1988.

[36] Westbrook CK. Chemical kinetics of hydrocarbon ignition in practical combustion systems. Proceedings of the Combustion Institute 2000;28:1563-77. doi:10.1016/S00820784(00)80554-8.

[37] Andree A, Pachernegg SJ. Ignition Conditions in Diesel Engines. SAE Paper 1969:690253. doi:10.4271/690253. 
[38] Stone R. Introduction to Internal Combustion Engines. 4th ed. New York: Palgrave Macmillan Limited; 2012.

[39] Miller JA, Bowman CTC. Mechanism and modeling of nitrogen chemistry in combustion. Progress in Energy and Combustion Science 1989;15:287-338. doi:10.1016/03601285(89)90017-8.

[40] Dec JE. A Conceptual Model of DI Diesel Combustion Based on Laser-Sheet Imaging. SAE Paper 1997:970873. doi:10.4271/970873.

[41] Zeldovich Y, Frank-Kamenetskii D, Sadovnikov P. Oxidation of Nitrogen in Combustion. Publication House of the Academic of Sciences of USSR; 1947.

[42] Bowman CT. Kinetics of nitric oxide formation incombustion processes. Symposium (International) on Combustion 1973;14:729-38. doi:10.1016/S0082-0784(73)80068-2. 